\title{
6. CALCAREOUS-NANNOFOSSIL BIOSTRATIGRAPHY, NAURU BASIN, DEEP SEA DRILLING PROJECT SITE 462, AND UPPER CRETACEOUS NANNOFACIES1
}

\author{
Hans R. Thierstein, Scripps Institution of Oceanography, University of California, San Diego, \\ La Jolla, California \\ and
}

Helène Manivit, C.N.R.S. and Laboratoire de Palynologie, BRGM, B.P. 6009, 45018 Orleans Cedex, France

\begin{abstract}
The deep-sea sediments recovered at Deep Sea Drilling Project Site 462 are of middle Cretaceous through Pleistocene age. The biostratigraphic age assignments based on calcareous nannofossils as given in the Site Summary (this volume) are documented here in detail, and an attempt to recognize the depth-provenance of Upper Cretaceous nannofossil carbonate in the nannofacies is explained and illustrated.
\end{abstract}

\section{BIOSTRATIGRAPHY}

Holes 462 and $462 \mathrm{~A}$ were drilled in the Nauru Basin (western central Pacific), in 5189 and 5186 meters of water. They are at the foot of the northeastern slope of the Ontong-Java Plateau, at $07^{\circ} 14^{\prime} \mathrm{N}$ and $165^{\circ} 02^{\prime} \mathrm{E}$, slightly off the up-slope axis of a northeast-trending deep-sea channel (Fig. 1). This topographic setting is reflected in the lithologies of the sediments and in the composition of most microfossil assemblages recovered. The sediments from large parts of the section are finegrained, distal turbidites. Particularly in the Neogene sequence, the calcareous nannofossils, as observed in smear slides under the light microscope, are packed in radiolarian-test fragments, which are dominantly in the 20 - to $50-\mu \mathrm{m}$ size range. Comparatively few, isolated coccoliths were observable in these slides; in many cases the radiolarian tests had to be crushed and the coccoliths dispersed on the slide to provide a sufficient number of isolated and identifiable nannofossil specimens. Apparent lateral transport of sediment particles also resulted in mixed fossil assemblages, in which the reworked portion of the nannoflora often exceeded the younger, indigenous portion. Some of the apparent age discrepancies among the various microfossil groups (Figs. 2-4; Site Summary, this volume) may be related to these differential-transport mechanisms. Other biostratigraphic inconsistencies, as in the sediments in Cores 5 to 8 , may be related to hole collapse, favored by the sandy nature of the sediments in the uppermost part of the hole.

The abundance, preservation, and stratigraphic distribution of identified calcareous nannofossils are listed in Figures 5 to 8 (Figs. 5 and 7 are in back pocket, this volume).

The full generic and specific names of all taxa considered in this report, and references to authors, are given in Table 1. The estimated relative abundances of each taxon as shown in Figures 5 to 8 are on a logarith-

\footnotetext{
${ }^{1}$ Initial Reports of the Deep Sea Drilling Project, Volume 61
}

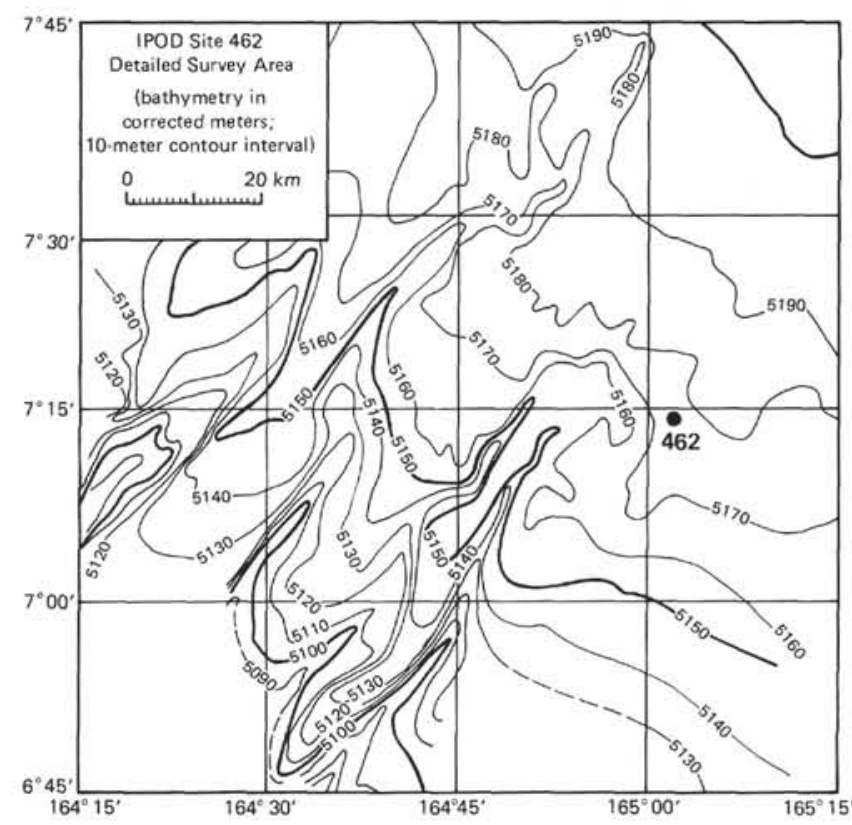

Figure 1. Geographic and bathymetric location of Site 462 .

mic scale. Lower-case letters indicate that the taxon is considered reworked. Abundances and preservational data given in the left-hand column next to the subbottom depths, refer to the whole assemblage. Preservation is described as etching or overgrowth, both on a scale of 0 to 3 , following the scheme developed by Roth and Thierstein (1972). The estimated proportion of reworked nannofossils in the examined assemblages is also listed in the left-hand column. The Cenozoic range charts for Holes 462 and 462A (Figs. 5 [back pocket] and 6) include the encountered taxa that were considered stratigraphically useful. The zonal scheme indicated is Martini's (1971) numbered standard zonation; stratigraphic criteria from Bukry $(1973,1975)$, however, have also been used with the correlation between the two zonal schemes as given in Bukry (1978). The Mesozoic range charts (Figs. 7 [back pocket] and 8) show all recognizable nannofossil taxa. The Campanian 


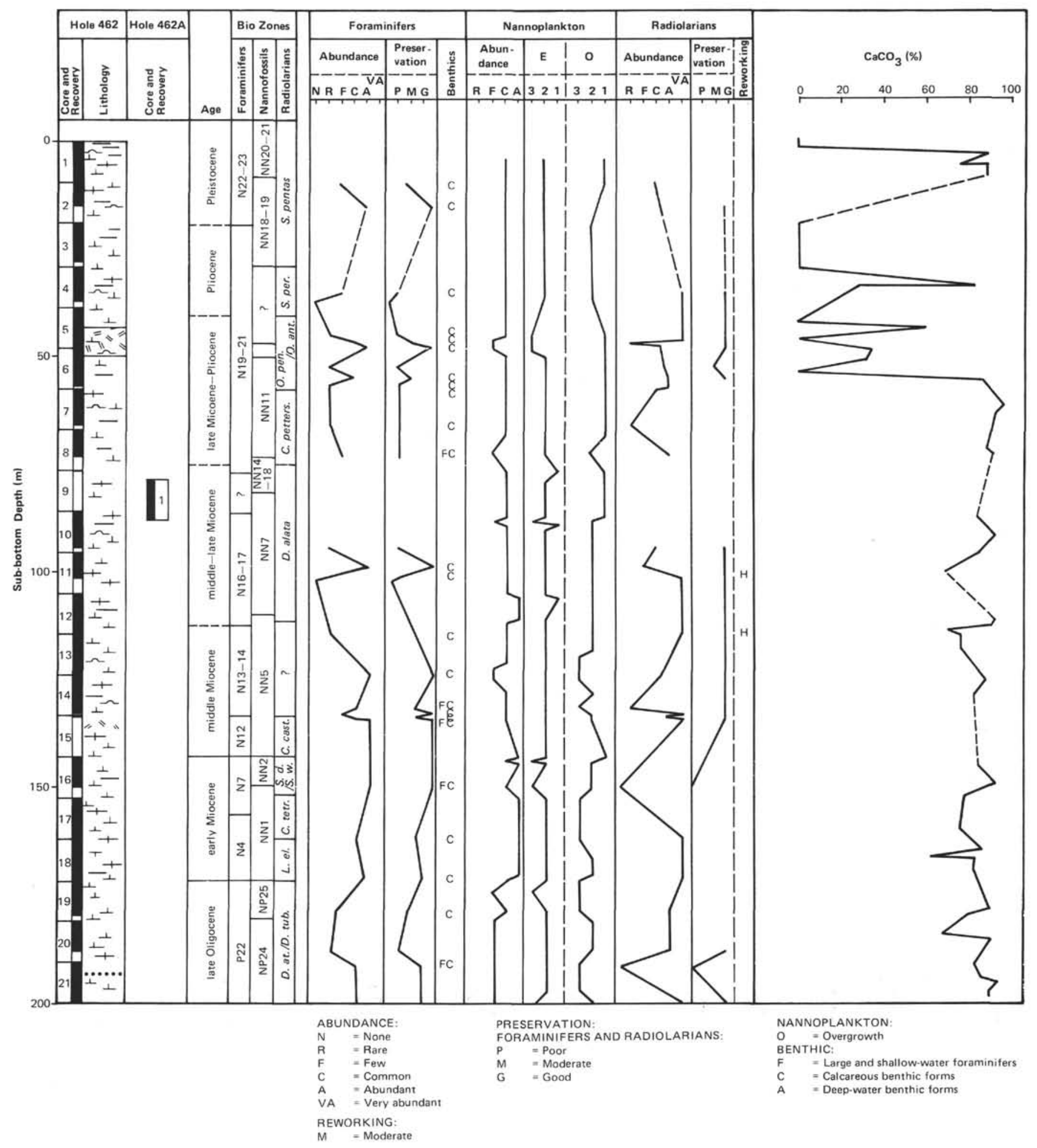

Figure 2. Neogene stratigraphy of Site $\mathbf{4 6 2}$ (see also Site Summary, this volume). 


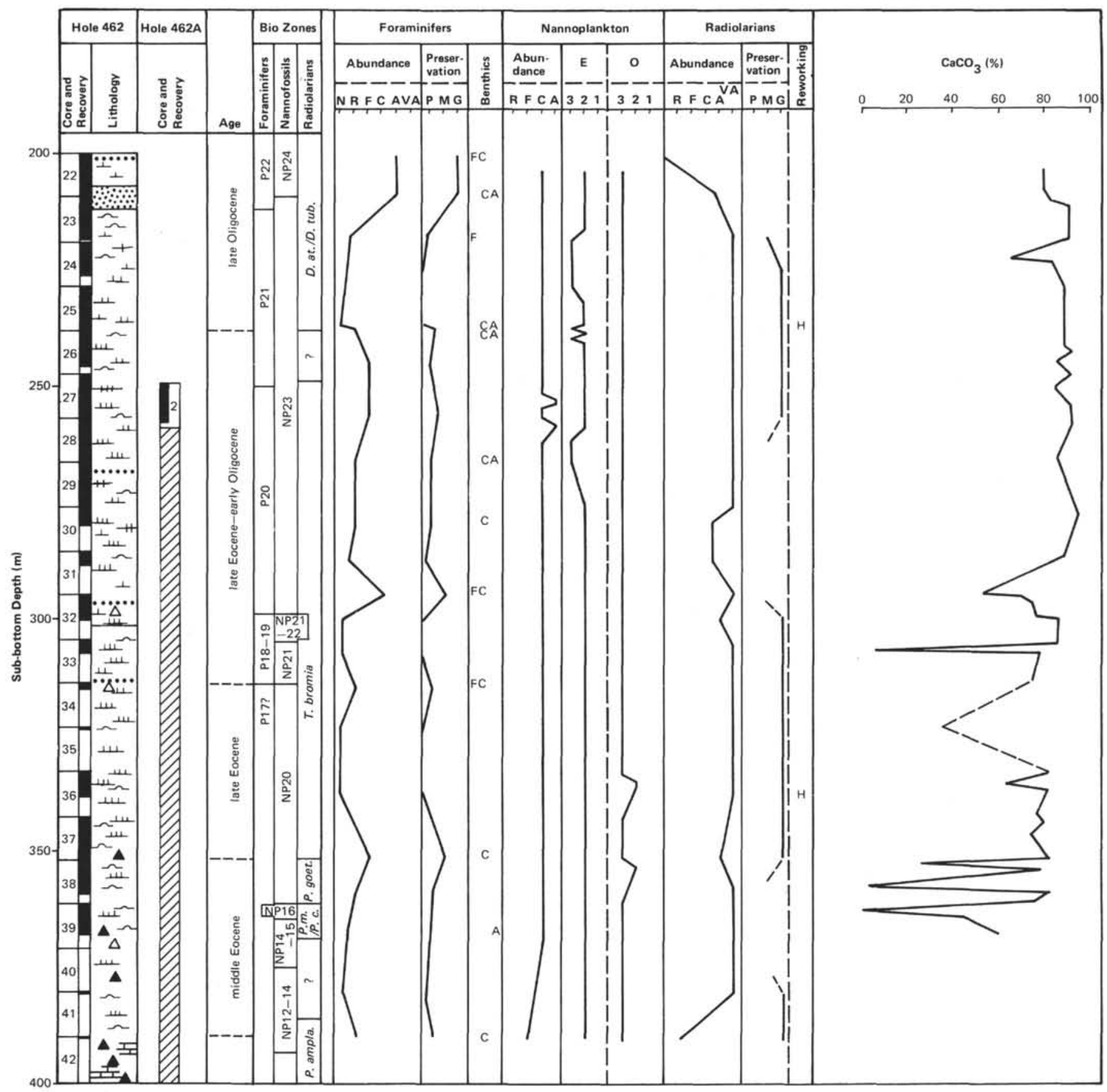

Figure 3. Paleogene stratigraphy of Site 462 (see also Site Summary, this volume). Symbols as in Figure 2.

and Maestrichtian zonation is that proposed by Verbeek (1977). Pre-Campanian assemblages cannot be assigned readily to a particular zone. Stratigraphic correlations are discussed individually below.

\section{Core 1 (0-9 m)}

Pleistocene, based on the appearance of $G$. oceanica and the abundance and decrease of $P$. lacunosa, and on the planktonic foraminifers.

\section{Cores 2 through 5 (9-48 m)}

Late Pliocene to Pleistocene, based on the presence of $G$. caribbeanica, C. cristatus, $P$. lacunosa, and $D$. asymmetricus, and the abundance of $D$. brouweri, $D$. pentaradiatus, and $D$. surculus. This age assignment is in agreement with the'planktonic foraminifers. The presence of Pliocene D. asymmetricus in Core 4, and of C. cristatus in Core 5, indicates that the late Miocene radiolarians in these cores must be reworked. 


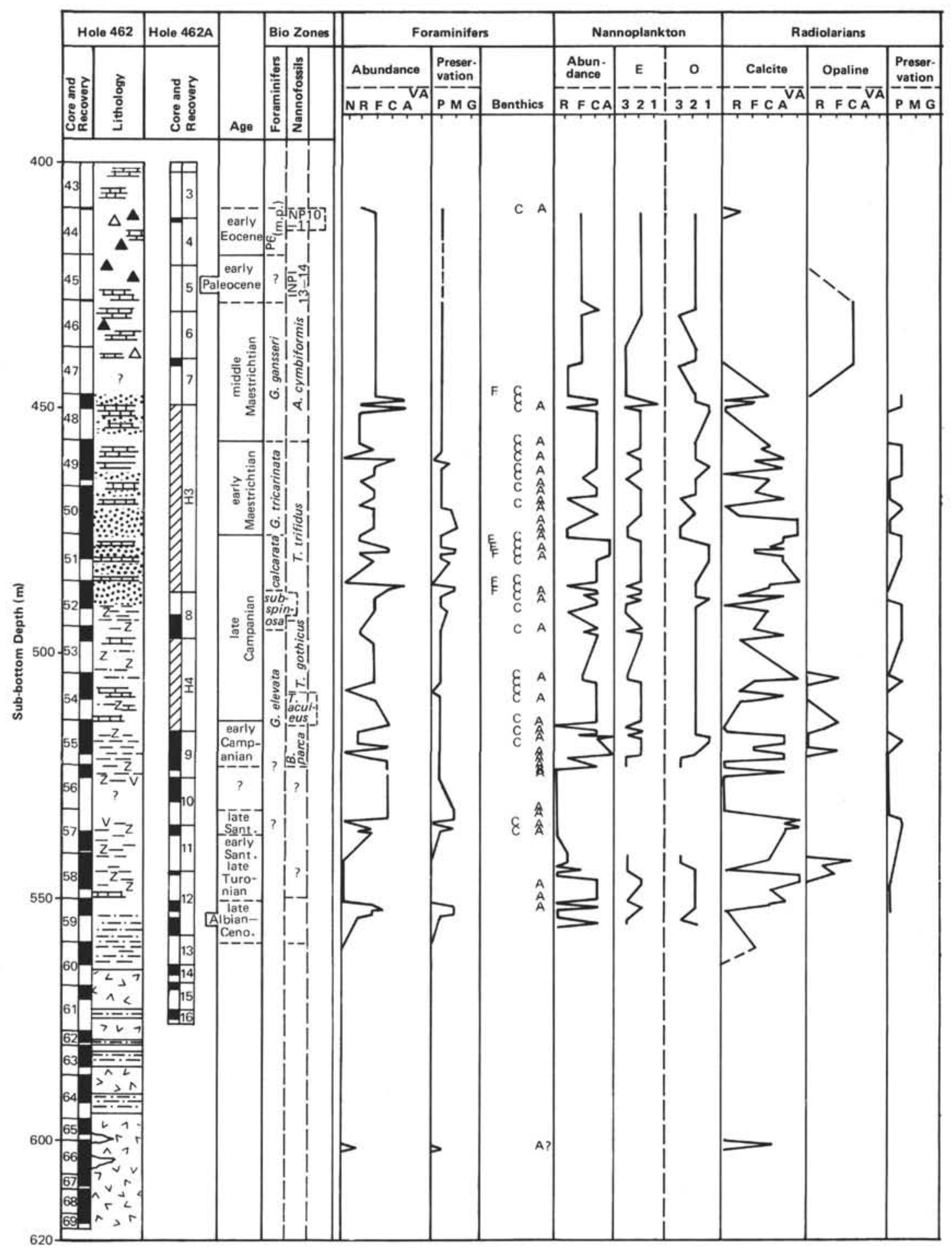

Figure 4. Mesozoic stratigraphy of Site 462 (see also Site Summary, this volume). Symbols as in Figure 2.

\section{Cores 6 through $8(49-76 \mathrm{~m})$}

Stratigraphic interpretation of this sequence is ambiguous. All samples examined in this interval (see Fig. 5 ), with the exception of $8, \mathrm{CC}$, contain late Miocene nannofossil assemblages. This age assignment is corroborated by radiolarians. The nannofossil assemblage from 8,CC contains latest Pliocene or younger species, such as G. caribbeanica, C. cristatus, and P. lacunosa, which however would be considerably younger than the early Pliocene foraminifers encountered in Cores 7 and 8 (Premoli Silva and Violanti, this volume). The possibility of down-hole contamination cannot be ruled out.

\section{Core 1A, Cores 10 through 15 (79-143 m)}

Middle Miocene, based on the presence of D. kugleri in Cores 1A, 10,11, and the top of 12, and of S. heteromorphus and D. exilis in Cores 12 through 15 . This age 


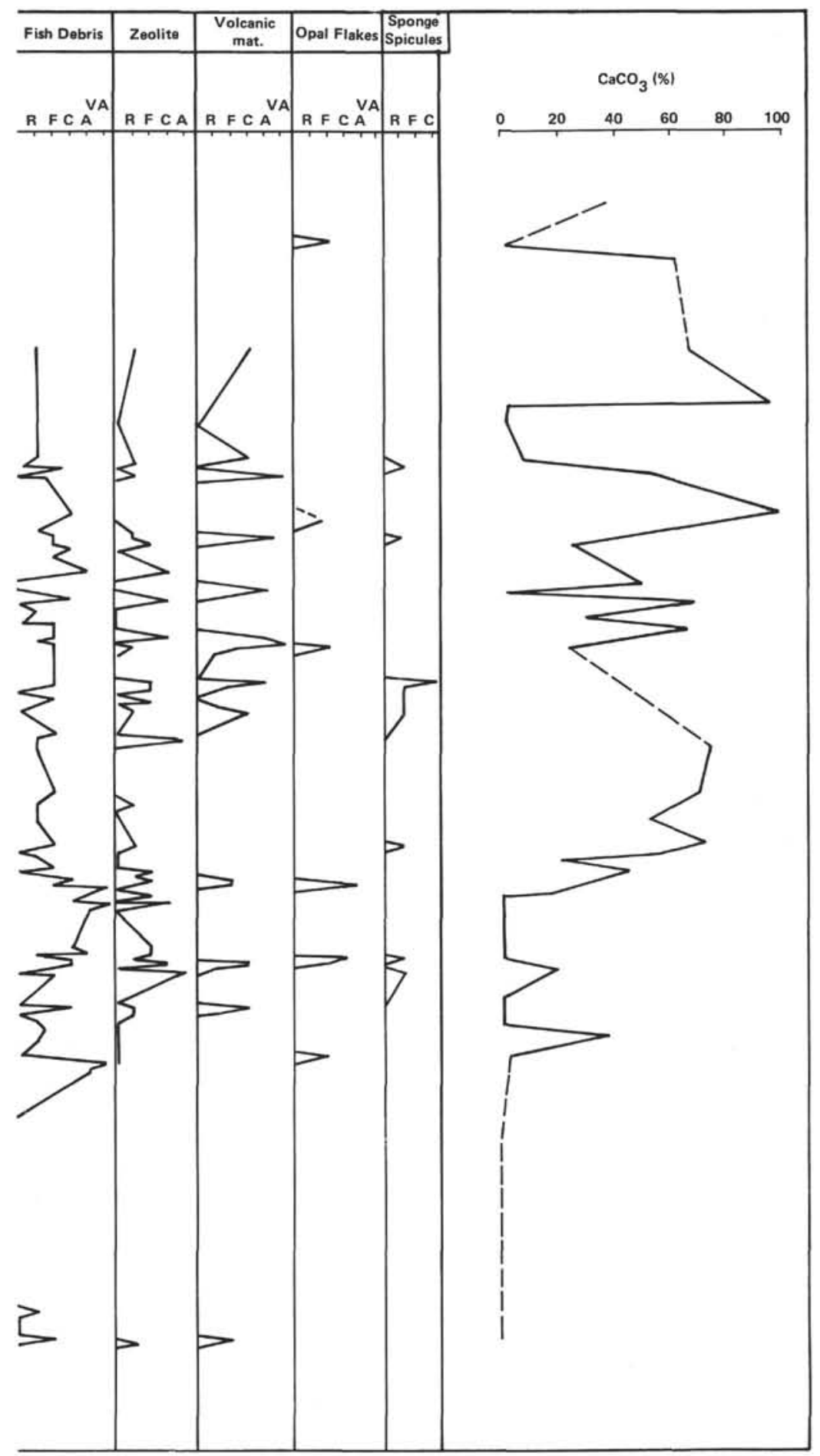

Figure 4. (Continued).

is confirmed by radiolarians. Planktonic foraminifers are interpreted as late Miocene in age. No late middle Miocene or late Miocene marker nannofossils could be identified in any of seven assemblages examined within this interval; their absence might, however, be due to moderate to poor preservation.

\section{Cores 16 through $18(150-171 \mathrm{~m})$}

Early Miocene, based on the presence of $D$. druggii in Core 16 , Section 1 , and of $T$. carinatus in Core 16 through Core 19, Section 2. Radiolarians confirm this age. Planktonic-foraminifer assemblages are considered 


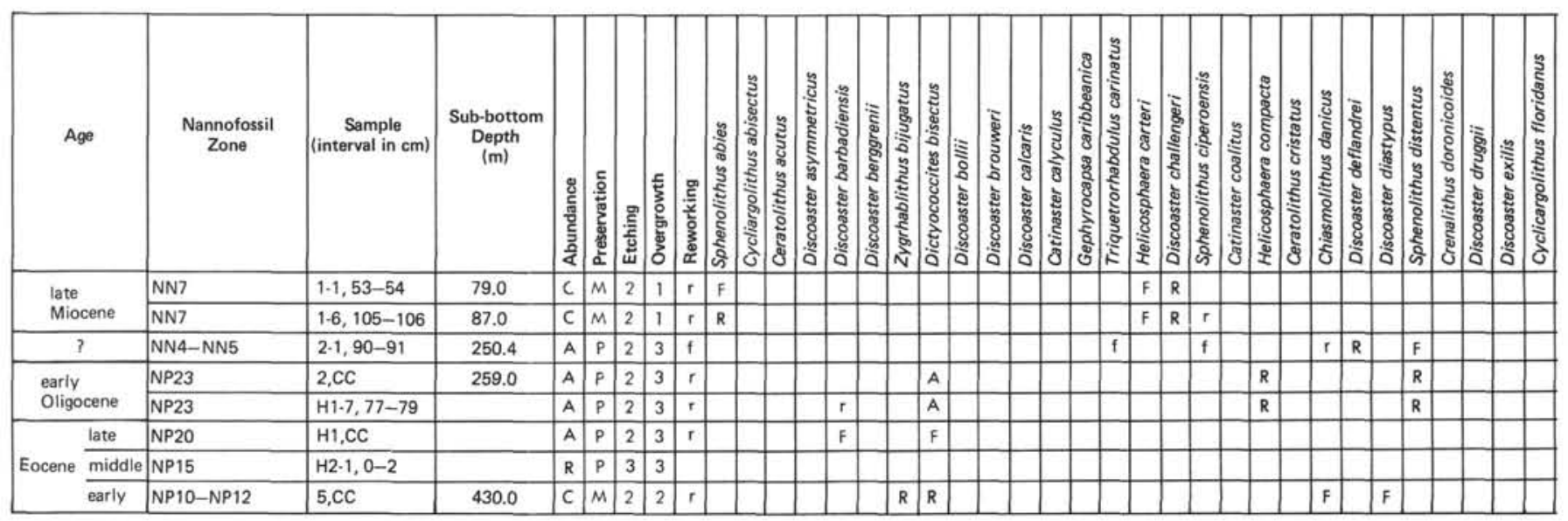

Figure 6. Stratigraphic distribution of Cenozoic calcareous nannofossils in Hole 462A. Symbols as in Figure 5 (back pocket, this volume).

to be somewhat younger, although still early Miocene, by Premoli Silva and Violanti (this volume).

\section{Cores 19 through 32, Section 2, Core 2A (174-297 m)}

Late Oligocene, based on the occurrence of S. ciperoensis in Cores 19 through 22, and S. distentus in Core 19 to Core 32, Section 2. The early/late Oligocene boundary is placed in Core 32, based on planktonic-foraminifer evidence. The radiolarians are of late Eocene age below Core 27, Section 2, and are considered reworked, an interpretation that is supported by abundant late Eocene nannofossils and very rare Oligocene marker species encountered in this interval.

\section{Cores 32 (bottom) and 33 (304-314 m)}

Early Oligocene, based on the absence of $D$. saipanensis in Core 33. Planktonic foraminifers confirm this age assignment; whereas radiolarians indicate a late Eocene age and may be reworked.

\section{Cores 34 to 38 (314-361.5 m)}

Late Eocene, based on the co-occurrence $S$. moriformis, S. pseudoradians, $H$. reticulata, and D. saipanensis in Cores 34 through 38. This age assignment correlates well with the planktonic foraminifers and radiolarian ages.

\section{Core 39 (361.5-371 m)}

Middle Eocene, based on the co-occurrence of $S$. furcatolithoides, C. grandis, D. kuepperi, C. solitus, and R. umbilica.

\section{Cores 40 through 44, and Core 5A (390-410 m)}

Early Eocene, based on the occurrence of $D$. barbadiensis, $D$. diastypus, $C$. formosus, and D. multiradiatus in some or all samples from Cores 40 through 44 . This age is in agreement with that inferred from planktonic foraminifers. The lowermost Cenozoic radiolarian assemblage encountered at this site is from Core 41 and is considered of middle Eocene age.

\section{Core $45(428 \mathrm{~m})$}

Early Paleocene, based on the presence of $C$. danicus, $Z$. sigmoides, and C. tenuis.

Core 46 through Core 48, Section 2, Core 7A (437-449 m)

Middle Maestrichtian, based on the absence of $T$. gothicus, T. trifidus, and L. quadratus. This age assignment is confirmed by the planktonic foraminifers.

\section{Cores 48 (bottom) through Core 52, Core 8 A (top) 456-494 m)}

Late Campanian to early Maestrichtian, based on the presence of $T$. trifidus. This age is confirmed by the planktonic foraminifers.

\section{Cores 53 through 54, Core 8A (below Section 1) (489-512 m)}

Late Campanian, based on presence of $C$. aculeus and $T$. gothicus. This age assignment agrees with the evidence from planktonic foraminifers.

\section{Core 55 and Core 9A (514-522.5 m)}

Early Campanian, based on the presence of $B$. parca. Planktonic foraminifers confirm this age assignment.

Core 56 through Core 58, Core 11A, Core 12A (upper part) (522.5-549 m)

Turonian to Santonian, based on the presence of $M$. decoratus, $M$. staurophora, and $L$. floralis in this inter$\mathrm{val}$, as well as on the age of the nannofossil assemblages above and below. There is no contrary evidence from the few poorly preserved planktonic-foraminifer assemblages encountered in Core 57.

Core 59, Section 1, Core 12A (lower part), and Core 13A (top) (549-553 m)

Late Albian to Cenomanian, based on the co-occurrence of $C$. chiastia, $C$. signum, $E$. turriseiffelii, and 


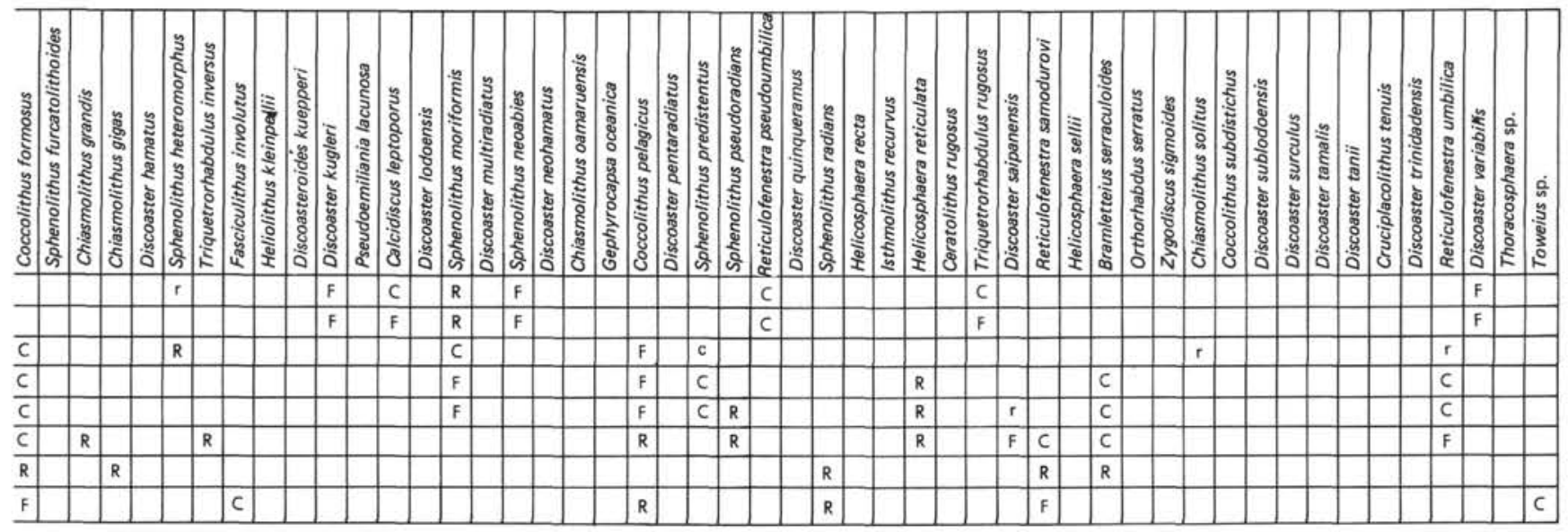

Figure 6. (Continued).

Cylindralithus spp., and questionable $L$. alatus. Only five samples of a total of 21 samples examined contained any calcareous nannofossils.

\section{Core 40A, Section 1 (702 m)}

A single sample with a poorly preserved early Cretaceous nannofossil assemblage was recovered from the sediments within the basalts. The presence of $L$. floralis and $C$. chiastia limits its age range to late Aptian through Cenomanian; the absence of $P$. cretacea and other Albian marker species also indicates a likely age of late Aptian to earliest Albian for the nannofossils in Core 40A.

An additional 16 smear slides examined from sediments in Cores $40 \mathrm{~A}$ through $44 \mathrm{~A}$, as indicated on the core-description sheets in chapter 2 , the site summary, were barren of calcareous nannofossils.

\section{TAXONOMIC NOTES}

A light-microscope examination of nannofossil assemblages from the lower Austin Chalk along Farm Road 1382, South Dallas County, Texas, the type locality of Watznaueria oblonga Bukry (1969), has revealed the presence of specimens of Flabellites biforaminis Thierstein (1973) without an asymmetric flange. Since symmetric specimens were included in the original definition of $F$. biforaminis, this species is considered a junior synonym of Watznaueria oblonga Bukry (1969), as proposed by Bukry (1975). Original description and illustrations of $W$. oblonga by Bukry (1969) were limited to the distal side of the coccolith. Thierstein's (1973) holotype and paratypes of $F$. biforaminis are herein designated as hypotypes of $W$. oblonga, and the definition of $W$. oblonga is amended to include the characteristics, size range, and stratigraphic distribution of $F$. biforaminis as given in Thierstein (1973).

\section{NANNOFACIES OF LATE CRETACEOUS SEDIMENTS}

The purpose of this preliminary study was to elucidate the character and provenance of the Upper Cretaceous carbonate sequence at Site 462. A descent of the $\mathrm{CCD}$ in the central Pacific in the Campanian-Maes- trichtian interval had originally been postulated by Winterer (1973), and has been documented recently by Thierstein (1979). Only a limited number of DSDP sites have been drilled previously in the Pacific on deep and old oceanic crust, and most of these sites were cored intermittently. The data coverage in an age-paleodepth framework was therefore rather spotty (Fig. 9), and the carbonate-deposition patterns could be delineated only in a tentative way (Fig. 10). Continuous coring at DSDP Site 462 in a basinal setting therefore had the potential of significantly improving the scant data base available.

With the recovery of volcaniclastic sediments with late Cretaceous shallow-water large benthic foraminifers in Cores 48, 51, and 52 of Hole 462, the question arose whether not all the carbonate deposited in Upper Cretaceous sediments had been transported from shallower elevations. There is no positive evidence to rule out such transport. The absence of positive evidence for transport, and the similarity of the preserved carbonate record at this site with the regional patterns known from other DSDP sites, may serve as guides to paleoceanographic interpretations.

The carbonate record of Site 462 corresponds well to the regionally observed patterns in the deep central $\mathrm{Pa}$ cific, as shown in Figure 10. The paleodepth for Site 462 was determined by assuming a basement age of 160 m.y., and by back-tracking along a standard oceaniccrust-subsidence curve. The intrusion of the basaltic sill complex, of at least 550-meters thickness, is assumed to have occurred prior to the Campanian. It may have reset the exponentially decreasing subsidence curve during its intrusion, which would have resulted in a Campanian paleodepth a few hundred meters shallower than shown on Figure 10, at best, assuming significant reheating of the underlying lithosphere (see Larson and Schlanger, this volume). The similarity of the carbonate preservation at Site 462 to that at other sites of different tectonic and topographic setting suggests that the CCD variation observed in the central Pacific is of regional oceanic rather than local tectonic and topographic significance.

Additional support for such an interpretation may be derived from the rather intermittent occurrence of posi- 


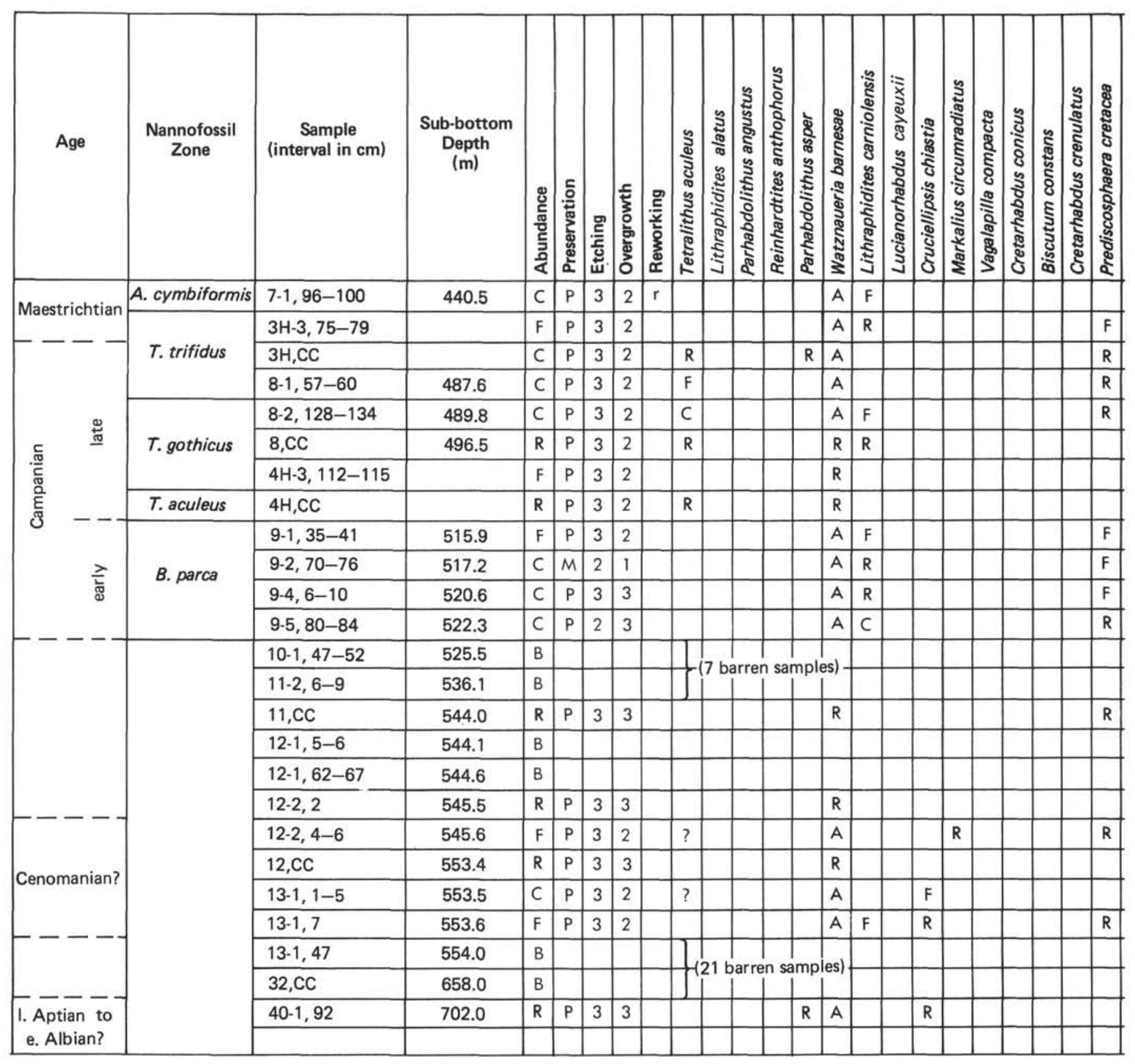

Figure 8. Stratigraphic distribution of Mesozoic calcareous nannofossils in Hole 462A. Symbols as in Figure 5 (back pocket, this volume).

tive evidence for transport found in the lithology and the benthic deep-water foraminifers (Sliter, this volume). We have studied the nannofacies of the lowermost part of the Upper Cretaceous carbonate sequence which was recovered below the obviously transported volcaniclastic upper Campanian to lower Maestrichtian interval. The analyzed sequence consists of partially burrowed, interlayered claystones, marlstones, and limestones in Cores 54 and 55, from a sub-bottom depth of 509 to 522.5 meters. Within that interval, we have examined the nannofacies of 20 samples. Eleven of these samples, covering the characteristic lithologies, are dis- cussed in detail below (see Table 2). Listed in Table 2 are the abundance of calcareous nannofossils, the inferred provenance (autochthonous or allochthonous) of benthic foraminifers (after Sliter, this volume), the per cent bulk calcium carbonate, and respective illustrations of the nannofacies.

We attempted to recognize differences in the nannofacies between intervals with apparently transported foraminifer assemblages and intervals with no evidence for transport in either the coarse fraction or the lithology. Features for transport might include changes in preservation of nannofossils, their average sizes, lami- 


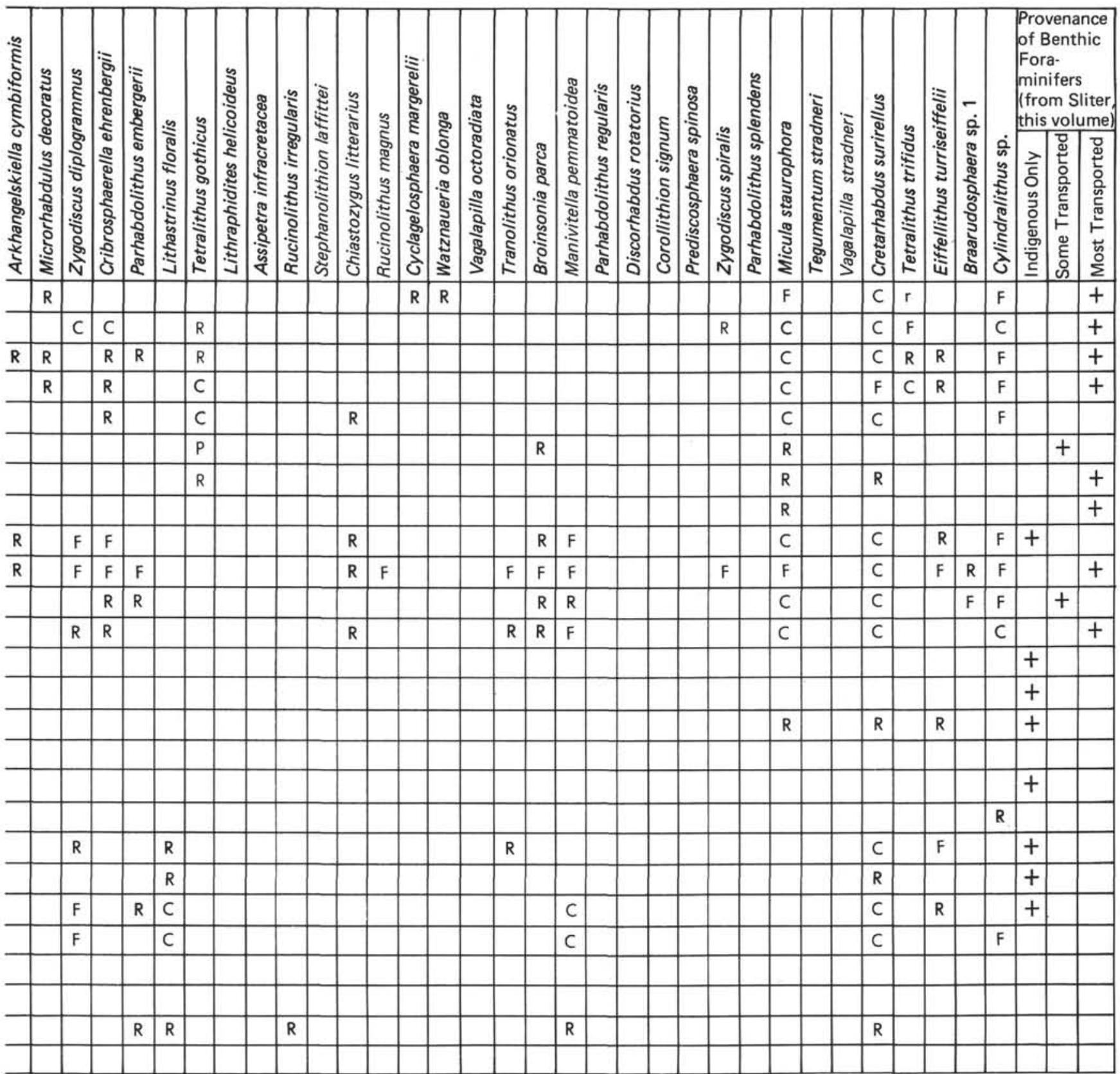

Figure 8. (Continued).

nations and preferred orientations, changes in the frequency of individual taxa and of coccospheres, degree of lithification, and possibly others.

The nannofacies was studied by Manivit with a scanning electron microscope (SEM), on broken surfaces of bulk samples. Methodology and terminology have previously been described by Noël (1968) and Noël and Melguen (1978). Differentation of clay and carbonate particles was done with the aid of an ORTEC energydispersive X-ray system. The following discussion of the individual studied samples proceeds from bottom to top and refers to the illustrations in Plates 1 to 6 .

\section{Sample 462-55,CC (Plate 1, Figs. 4-6)}

The dark-gray, silty claystone has a carbonate content of $16 \%$ and is at the base of the latest Cretaceous carbonate interval. None of the eight samples from the underlying 12 meters of zeolitic claystones contained any carbonate microfossils or measurable carbonate contents. Only two poorly preserved planktonic foraminifers (Heterohelix sp. and Hedbergella sp.) were recovered from this sample in the 63- to $50-\mu \mathrm{m}$ fraction. Rare and poorly preserved agglutinated benthic foraminifers are considered indigenous (Sliter, this volume). 
Table 1. Calcareous-nannofossil taxa considered in this report.

\section{Cenozoic}

Sphenolithus abies Deflandre, 1954

Cyclicargolithus abisectus (Müller, 1970) Bukry, 1973

Ceratolithus acutus Gartner and Bukry, 1974

Discoaster asymmetricus Gartner, 1969

Discoaster barbadiensis Tan 1927

Discoaster berggrenii Bukry, 1971

Zygrhablithus bijugatus (Deflandre, 1954) Deflandre, 1959

Dictyococcites bisectus (Hay, Mohler and Wade, 1966) Bukry and Percival, 1971

Discoaster bollii Martini and Bramlette, 1963

Discoaster brouweri Tan 1927

Discoaster calcaris Gartner, 1967

Catinaster calyculus Martini and Bramlette, 1963

Gephyrocapsa caribbeanica Boudreaux and Hay, 1967

Triquetrorhabdulus carinatus Martini, 1965

Helicosphaera carteri (Wallich, 1877) Kamptner, 1954

Discoaster challengeri Bramlette and Riedel, 1954

Sphenolithus ciperoensis Bramlette and Wilcoxon, 1967

Catinaster coalitus Martini and Bramlette, 1963

Helicosphaera compacta Bramlette and Wilcoxon, 1967

Ceratolithus cristatus Kamptner, 1950

Chiasmolithus danicus (Brotzen, 1959) Hay and Mohler, 1967

Discoaster deflandrei Bramlette and Riedel, 1954

Discoaster diastypus Bramlette and Sullivan, 1961

Sphenolithus distentus (Martini, 1965) Bramlette and Wilcoxon, 1967

Crenalithus doronicoides (Black and Barnes, 1961) Roth, 1973

Discoaster druggi Bramlette and Wilcoxon, 1967

Discoaster exilis Martini and Bramlette, 1963

Cyclicargolithus floridanus (Roth and Hay, 1967) Bukry, 1971

Cyclicargolithus floridanus (Roth and Hay, 1967) Bukry
Coccolithus formosus (Kamptner, 1963) Wise, 1973

Coccolithus formosus (Kamptner, 1963) Wise,

Sphenolithus furcatolithoides Locker, 1967
Chiasmolithus grandis (Bramlette and Sullivan, 1954) Radomski, 1968

Chiasmolithus gigas (Bramlette and Sullivan, 1954) Radomski, 1968

Discoaster hamatus Martini and Bramlette, 1963

Sphenolithus heteromorphus Deflandre, 1953

Triquetrorhabdulus inversus Bukry and Bramlette, 1969

Fasciculithus involutus Bramlette and Sullivan, 1961

Heliolithus kieinpellii Sullivan, 1964

Discoasteroides kuepperi (Stradner, 1959) Bramlette and Sullivan, 1961

Discoaster kugleri Martini and Bramlette, 1963

Pseudoemiliania lacunosa (Kamptner, 1963) Gartner, 1969

Calcidiscus leptoporus (Murray and Blackman, 1898) Loeblich and Tappan, 1978

Discoaster lodoensis Bramlette and Riedel, 1954

Sphenolithus moriformis (Bronnimann and Stradner, 1960) Bramlette and Wilcoxon, 1967

Discoaster multiradiatus Bramlette and Riedel, 1954

Sphenolithus neoabies Bukry and Bramlette, 1969

Discoaster neohamatus Bukry and Bramlette, 1969

Chiasmolithus oamaruensis (Deflandre, 1954) Hay, Mohler and Wade, 1966

Gephyrocapsa oceanica Kamptner, 1943

Coccolithus pelagicus (Wallich, 1877) Schiller, 1930

Discoaster pentaradiatus Tan 1927

Sphenolithus predistentus Bramlette and Wilcoxon, 1967

Sphenolithus pseudoradians Bramlette and Wilcoxon, 1967

Reticulofenestra pseudoumbilica (Gartner, 1967) Gartner, 1969

Discoaster quinqueramus Gartner, 1969

Sphenolithus radians Deflandre, 1952

Helicosphaera recta (Haq, 1966) Jafar and Martini, 1975

Isthmolithus recurvus Deflandre, 1954

Helicosphaera reticulata Bramlette and Wilcoxon, 1967

Ceratolithus rugosus Bukry and Bramlette, 1968

Triquetrorhabdulus rugosus Bramlette and Wilcoxon, 1967

Discoaster saipanensis Bramlette and Riedel, 1954

Reticulofenestra samodurovii (Hay, Mohler and Wade, 1966) Roth, 1970

Helicosphaera sellii (Bukry and Bramlette, 1969) Jafar and Martini, 1975

Bramletteius serraculoides Gartner, 1969

Orthorhabdus serratus Bramlette and Wilcoxon, 1967

Zygodiscus sigmoides Bramlette and Sullivan, 1961

Chiasmolithus solitus (Bramlette and Sullivan, 1961) Locker, 1968

Coccolithus subdistichus (Roth and Hay, 1967) Bukry, 1971

Discoaster sublodoensis Bramlette and Sullivan, 1961

Discoaster surculus Martini and Bramlette, 1963

Discoaster tamalis Kamptner, 1967

Discoaster tanii Bramlette and Riedel, 1954

Cruciplacolithus temuis Hay and Mohler, 1967

Discoaster trinidadensis Hay, 1967

Reticulofenestra umbilica (Levin, 1966) Martini and Ritzkowski, 1968

Discoaster variabilis Martini and Bramlette, 1963

Thoracosphaera sp.

Toweius sp.

Mesozoic

Tetralithus aculeus (Stradner, 1961) Gartner, 1968

Lithraphidites alatus Thierstein, 1972

Parhabdolithus angustus (Stradner, 1963) Stradner, Adamiker and Maresch, 1968

Reinhardtites anthophorus (Deflandre, 1959) Perch-Nielsen, 1968

Parhabdolithus asper (Stradner, 1963) Manivit, 1971

Watznaueria barnesae (Black, 1959) Perch-Nielsen, 1968

Lithraphidites carniolensis Deflandre, 1963

Lucianorhabdus cayewxii Deflandre, 1959

Cruciellipsis chiastia (Worsley, 1971) Thierstein, 1972

Markalius circumradiatus (Stover, 1966)

Vagalapilla compacta Bukry, 1969

Cretarhabdus conicus Bramlette and Martini, 1964

Cretarhabdus conicus Bramlette and Martini,
Biscutum constans (Gorka, 1957) Black, 1967

Biscutum constans (Gorka, 1957) Black, 1967
Cretarhabdus crenulatus Bramlette and Martini, 1964

Prediscosphaera cretacea (Arkhangelsky, 1912) Gartner, 1968
Table 1. (Continued).

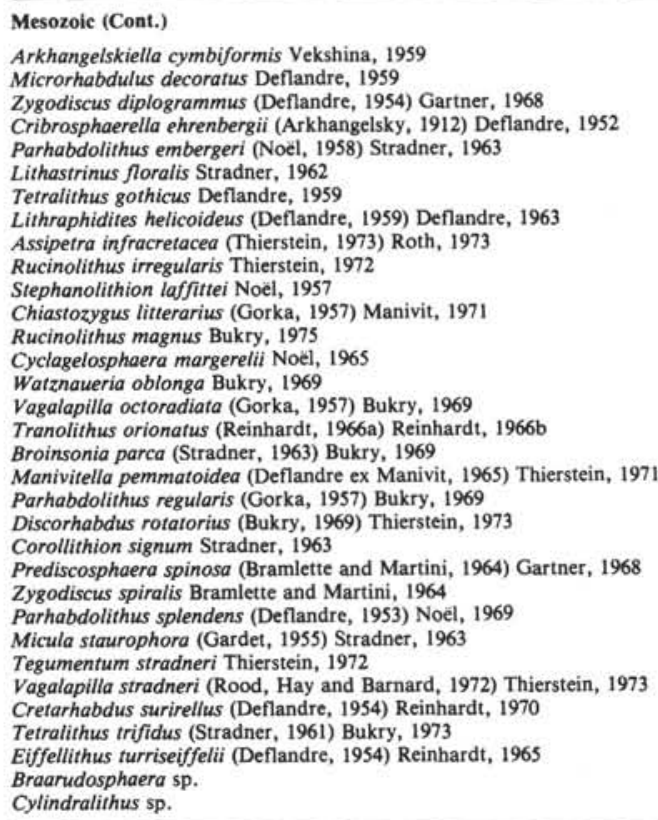

The very fine, clayey sediment is irregularly compacted, with holes in places, and is poorly structured. Clay particles are concentrated in large amorphous zones or in lamellae of variable thickness and of irregular shape. Nannofossils are visible only occasionally on the surfaces and are often deeply buried in the clay matrix, making their determination difficult. A red zeolitic claystone clast from the core catcher contained a few transported benthic foraminifers, but no calcareous nannofossils and no carbonate.

\section{Sample 462-55-4, 55-59 cm (Plate 2, Figs. 4-6)}

Pale brown, zeolitic marlstone contains $44 \%$ carbonate; rare deep-water benthic foraminifers, considered indigenous (Sliter, this volume); rare radiolarians; fish debris; and volcanic rock fragments.

Moderately etched and overgrown calcareous nannofossils dominate the nannofacies, despite the comparatively low carbonate content. Nannofossils are surrounded by a matrix of undulating clay laminae.

\section{Sample 462-55-2, 117-122 cm (Plate 1, Figs. 1-3)}

Brownish-gray claystone with $21 \%$ carbonate, and common, poorly preserved, mainly small planktonic and benthic foraminifers. Most benthic foraminifers are considered allochthonous, originating in shallower areas (Sliter, this volume).

Moderately well-preserved nannofossils are embedded in finely flaked, apparently diagenetically formed clay particles. Numerous fragments of coccoliths are dispersed in the fine clay matrix. No coccospheres were detected.

\section{Sample 462-55-2, 71-73 cm (Plate 2, Figs. 1-3)}

Tan, zeolitic marlstone contains $26 \%$ carbonate, common recrystallized radiolarians, little fish debris, 


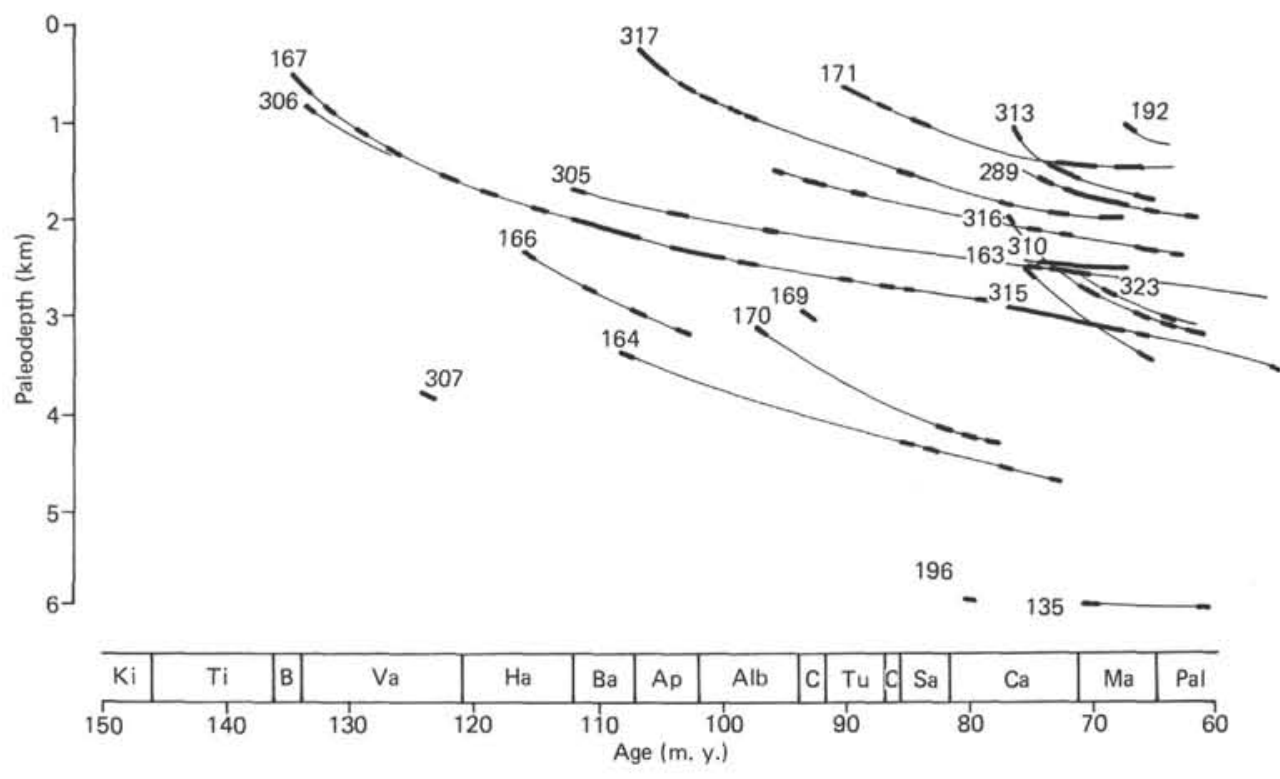

Figure 9. Back-tracked paleodepth of Pacific DSDP sites previously drilled on old oceanic crust (thin lines), and recovery of sediments (heavy lines). Modified from Thierstein (1979).

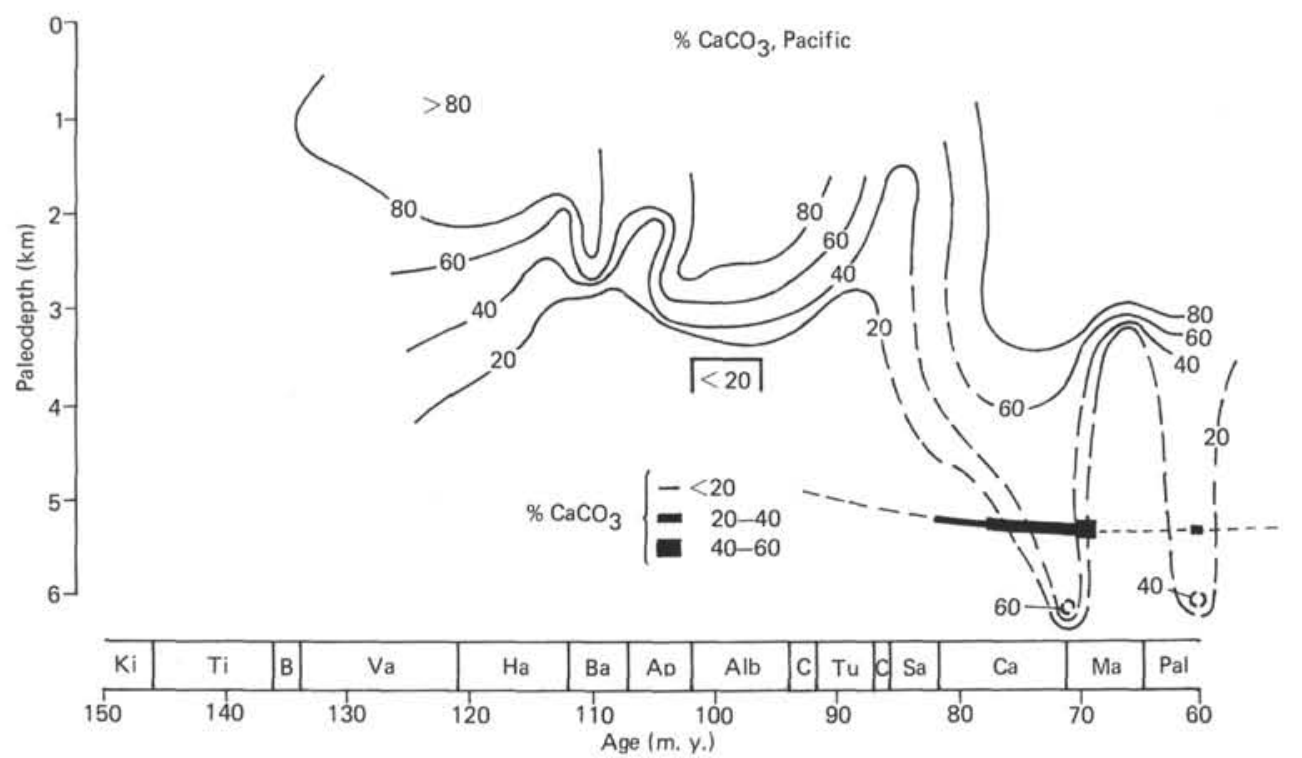

Figure 10. Mesozoic paleodepth and carbonate record of Site 462, and carbonate depositional patterns in the Pacific.

and few indigenous abyssal benthic foraminifers (Sliter, this volume).

Strongly etched and moderately overgrown nannofossils are dispersed in a compact clay matrix. Diagenetic dissolution of coccolith carbonate or diagenetic precipitation of clay minerals is evidenced by the occasional presence of coccolith imprints (e.g., Plate 2, Figs. $2,3)$. No coccospheres were detected.

Sample 462-55-2, 64-66 cm (Plate 4, Figs. 1-6)

Dark brown, zeolitic clay contains $2 \%$ carbonate, rare silicified radiolarian casts, and few squashed benthic foraminifers.
Rare calcareous nannofossils observed in smear slides in occasional lithified clay clasts of over $50 \mu \mathrm{m}$ were not found by SEM. The matrix consists of non-structured clay particles and pockets of cristobalite spherules.

Sample 462-55-2, 61-64 cm (Plate 3, Figs. 1-3)

Tan marlstone, with $55 \%$ carbonate, contains few planktonic foraminifers and few transported as well as rare indigenous deep-water benthic foraminifers, rare fish debris, and common, recrystallized radiolarians.

Common, moderately well-preserved calcareous nannofossils are dispersed in coccolith debris and clay matrix. Occasional coccospheres are present. 
Table 2. Samples with nannofacies analysis, Site 462 .

\begin{tabular}{|c|c|c|c|c|c|c|c|c|}
\hline $\begin{array}{c}\text { Sample } \\
\text { (interval in } \mathrm{cm} \text { ) }\end{array}$ & $\begin{array}{l}\text { Sub-bottom } \\
\text { Depth } \\
\text { (m) }\end{array}$ & Age & $\begin{array}{l}\text { Color of } \\
\text { Sediment }\end{array}$ & Lithology & $\begin{array}{l}\text { Abundance of } \\
\text { Nannofossils }\end{array}$ & $\begin{array}{l}\text { Provenance of } \\
\text { Benthic } \\
\text { Foraminifers } \\
\text { (after Sliter, } \\
\text { this volume) }\end{array}$ & $\underset{(\%)}{\mathrm{CaCO}_{3}}$ & Illustration \\
\hline $54-1,39-45$ & 509.39 & Late Campanian & White & $\begin{array}{l}\text { Chalk with } \\
\text { laminations }\end{array}$ & Frequent & Transported & 70 & Pl 6, Figs. 4 to 6 \\
\hline $54-1,123-126$ & 510.23 & Late Campanian & White & $\begin{array}{l}\text { Chalk with } \\
\text { burrows }\end{array}$ & Common & Transported & 69 & Pl. 6, Figs. 1 to 3 \\
\hline $54-3,3-7$ & 512.03 & Late Campanian & Grey & Chalk & Common & Transported & 60 & Pl. 5, Figs. 1, 2, 4 \\
\hline $55-1,85-89$ & 514.35 & Early Campanian & Brown & Marlstone & Common & Transported & 50 & Pl. 3, Figs. 4 to 6 \\
\hline $55-2,61-64$ & 515.61 & Early Campanian & Tan & Marlstone & Common & Transported & 55 & Pl. 3, Figs. 1 to 3 \\
\hline $55-2,64-66$ & 515.64 & Early Campanian & Brown & Claystone & Very rare & Indigenous only & 2 & Pl. 4 , Figs. 1 to 6 \\
\hline $55-2,71-73$ & 515.71 & Early Campanian & Tan & Marlstone & Frequent & Indigenous only & 26 & Pl. 2, Figs. 1 to 3 \\
\hline $55-2,117-122$ & 516.17 & Early Campanian & Grey & Marlstone & Abundant & Transported & 21 & Pl. 1, Figs. 1 to 3 \\
\hline $55-4,55-59$ & 518.55 & Early Campanian & Brown & Marlstone & Abundant & Indigenous only & 44 & Pl. 2, Figs. 4 to 6 \\
\hline
\end{tabular}

\section{Sample 462-55-1, 85-89 cm (Plate 3, Figs. 4-6)}

Brown marlstone contains $50 \%$ carbonate and common planktonic and benthic foraminifers of dominantly small size, and benthic foraminifers, probably transported.

Common to abundant, moderately to well-preserved calcareous nannofossils are embedded in flaky clay matrix. No coccospheres were observed.

\section{Sample 462-54-3, 3-7 cm (Plate 5, Figs. 1, 2, 4)}

Gray, marly limestone contains $60 \%$ carbonate and few, poorly preserved planktonic and transported benthic foraminifers.

The nannofacies consists of abundant calcareous nannofossils embedded in a relatively coarse and porous matrix of mainly coccolith debris. Overgrowth features dominate over solution features. No coccospheres were observed.

\section{Sample 462-54-2, 67-72 cm (Plate 5, Figs. 3, 5, 6)}

White, marly limestone with burrows has carbonate content of $60 \%$ and contains only indigenous, deepwater benthic foraminifers. Strongly etched and moderately overgrown calcareous nannofossils are tightly packed with carbonate debris and clay particles, apparently in preferred orientation. Nannofacies very different from that of Sample 462-54-3, 3-7 cm, despite identical bulk carbonate content.

\section{Sample 462-54-1, 123-126 cm (Plate 6, Figs. 1-3)}

White marly limestone with darker laminations has a carbonate content of $69 \%$. The coarse-fraction particles are all of relatively small size and include few planktonic and displaced (from up-slope) benthic foraminifers, rare radiolarians, and fish debris.

Common, moderately well-preserved and comparatively diverse calcareous nannofossils are found embedded in a matrix consisting mostly of nannofossil debris. Occasional coccospheres are present.
Sample 462-54-1, 39-45 cm (Plate 6, Figs. 4-6)

Brown, marly limestone with darker and lighter burrows has a carbonate content of $70 \%$. Coarse fraction consists of abundant recrystallized radiolarians, and few poorly preserved planktonic and benthic foraminifers, probably displaced from up-slope.

Moderately to well-preserved, relatively diverse calcareous nannofossils are found embedded in porous matrix of nannofossil debris and clay. Degree of recrystallization is variable. Partially intact coccospheres are encountered very commonly.

It becomes evident from the descriptions and illustrations of the nannofacies that there are no systematic differences on a presence-absence basis between the nannofacies of samples with apparently transported benthic foraminifers and those with only indigenous abyssal benthics. In samples with transported benthic foraminifers, coccospheres are encountered more frequently and more consistently, and nannofossil diversity is higher than in samples with only indigenous deep benthics. Dissolution experiments with Late Cretaceous nannofossil assemblages (Thierstein, 1980) have shown that a few solution-resistant taxa tend to become enriched rapidly in poorly preserved assemblages by dissolution of most of the other members of the assemblage, leading to a decrease in diversity. Rapid burial of particles in transported horizons should tend to preserve the higher diversity of shallower-water fossil assemblages, and indeed higher diversities are observed in samples with transported benthics than in those with only indigenous benthic foraminifers (see last column in Figs. 7 and 8).

\section{Campanian Braarudosphaera in the Nauru Basin}

A unique morphotype of Braarudosphaera (sp. indet.) was found in the Campanian sediments of Cores 55 and 9A. All specimens are considerably overgrown, as illustrated in Plate 7. Overgrowth appears to occur preferentially along one of the cleavage planes of the individual trigonal calcite crystals of the pentalith, pos- 
sibly aided by previous etching before burial. Asymmetric etching features on elements of pentaliths have been observed previously by Black (1972). The overgrowth of Braarudosphaera leads to buildup of the distal face and the development of a small central pit on the proximal side of the pentalith. The individual elements become radially asymmetric, and the sutures between the elements form an oblique, rather than perpendicular angle with the rotational-symmetry plane of the pentalith. Braarudosphaera (sp. indet.) are observed in samples with and without transported benthic foraminifers. The occurrence of Braarudosphaera in Holocene sediments is limited to well-preserved samples of less than $3 \mathrm{~km}$ water depth (Thierstein, 1980). Its apparent Recent preburial dissolution susceptibility and its occurrence in the Upper Cretaceous at Site 462 in samples with exclusively indigenous abyssal benthic foraminifers lend additional support to the interpretation of a descent of the CCD in the Pacific during the Campanian. The paleoecological and paleoceanographic implications of this first report of Braarudosphaera preserved in deep-sea sediments of Campanian age remain to be established.

\section{ACKNOWLEDGMENTS}

We thank Denise Noël for valuable discussions. Madame Cloiseau and the department of graphic arts (BRGM, Orléans) helped with the preparation of the manuscript and plates. Critical reviews by D. Bukry and F. Wind are acknowledged. Research was supported through NSF grant OCE76-22150 (H.R.T.) and through A.T.P. IPOD, R.C.P. 459 (H.M.).

\section{REFERENCES}

Black, M., 1972. Crystal development in Discoasteraceae and Braarudosphaeraceae (planktonic algae). Paleontology, 15:476-489.

Bukry, D., 1969. Upper Cretaceous coccoliths from Texas and Europe. Univ. Kansas Paleontol. Contr., 5 (Protista 2).
1973. Coccolith stratigraphy, eastern equatorial Pacific, Leg 16, Deep Sea Drilling Project. In van Andel, Tj. H., Heath, G. R., et al., Init. Repts. DSDP, 16: Washington (U.S. Govt. Printing Office), 653-711.

1975. Coccolith and silicoflagellate stratigraphy northwestern Pacific Ocean, Deep Sea Drilling Project Leg 32. In Larson, R. L., Moberly, R., et al., Init. Repts. DSDP, 32, Washington (U.S. Govt. Printing Office), 677-701.

1978. Biostratigraphy of Cenozoic marine sediments by calcareous nannofossils. Micropaleontology, 24:44-60.

Martini, E., 1971. Standard Tertiary and Quaternary calcareous nannoplankton zonation. In Forniacci, A. (Ed.), Proceedings of the II Planktonic Conference, Roma 1970 (Vol. 2): Rome (Ed. Technoscienza), 739-785.

Noël, D., 1968. Nature et genèse des alternances de marnes et de calcaires du Barrémier supérieur d'Angles (Fosse vocontienne BassesAlpes). C. R. Acad. Sci. Paris, 266:1223-1225.

Noël, D., and Melguen, M., 1978. Nannofacies of Cape Basin and Walvis Ridge sediments, Lower Cretaceous to Pliocene (Leg 40). In Bolli, W. M., Ryan, W. B. F., et al., Init. Repts. DSDP, 40: Washington (U.S. Govt. Printing Office), 487-524.

Roth, P. H., and Thierstein, H. R., 1972. Calcareous nannoplankton: Leg 14 of the Deep Sea Drilling Project. In Hayes, D. E., Pimm, A. C., et al., Init. Repts. DSDP, 14: Washington (U.S. Govt. Printing Office), 421-485.

Thierstein, H. R., 1973. Lower Cretaceous calcareous nannoplankton biostratigraphy. Abh. Geol. B.A. Wien, 29.

1979. Paleoceanographic implications of organic carbon and carbonate distribution in Mesozoic deep-sea sediments. In Talwani, M., and Ryan, W. B. F. (Eds.), Deep Drilling Results in the Atlantic Ocean: Continental Margins and Paleoenvironment: Washington (Am. Geophys. Union), pp. 249-274.

1980. Selective dissolution of late Cretaceous and earliest Tertiary calcareous nannofossils: experimental evidence. Cretaceous Res., 2:1-12.

Verbeek, J. W., 1977. Calcareous nannoplankton biostratigraphy of middle and upper Cretaceous deposits in Tunesia, southern Spain and France. Utrecht Micropaleont. Bull., 16.

Winterer, E. L., 1973. Regional Problems. In Winterer, E. L., Ewing, J. I., et al., Init. Repts. DSDP, 17: Washington (U.S. Govt. Printing Office), 911-922. 

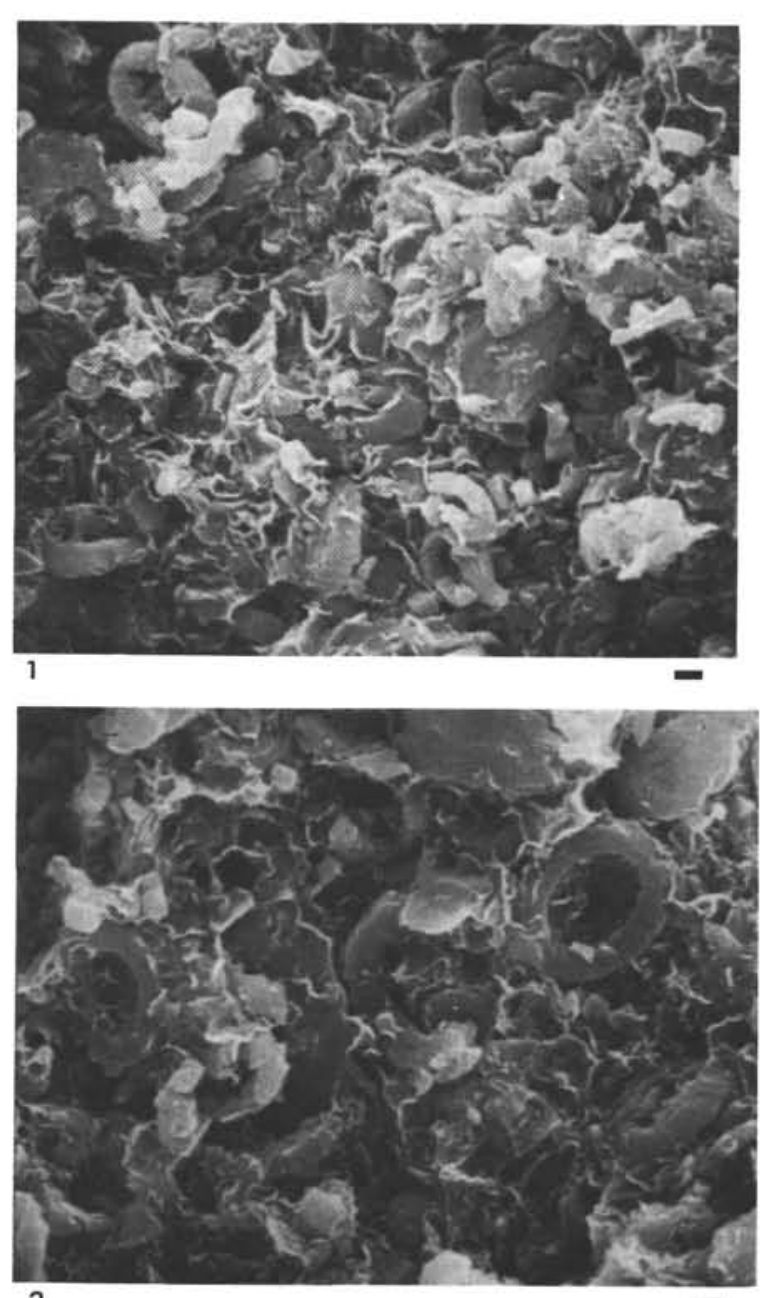

2

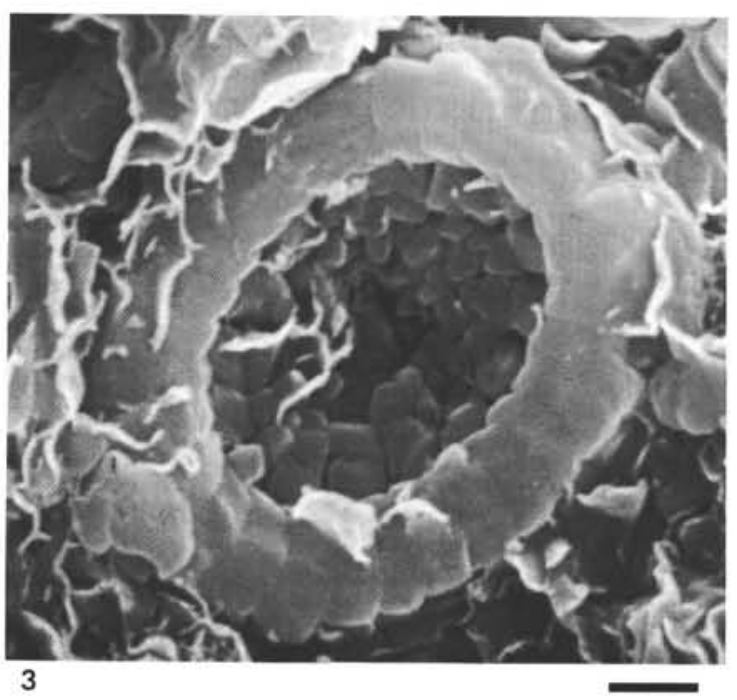

3

Plate 1. Scanning electron micrographs of lower Campanian nannofacies. Scale bars $=1 \mu \mathrm{m}$.

Figures 1-3. Sample 462-55-2, 117-122 cm. Marly claystone with transported benthic foraminifers. 1, 2. Abundant, moderately etched and slightly overgrown nannofossils embedded in finely dispersed clay matrix, $\times 3000$. 3. Detail of 2 , showing the proximal side of a slightly etched and overgrown coccolith, $\times 10,000$.
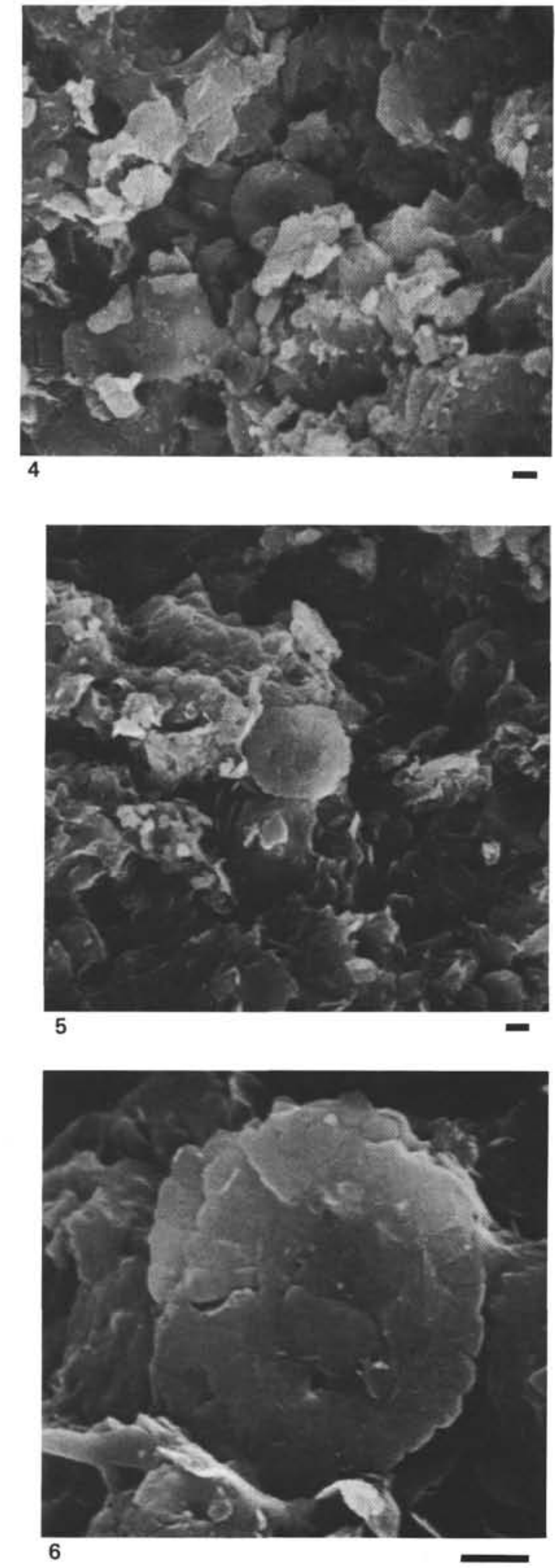

Figures 4-6. Sample 462-55,CC. Zeolitic marlstone with indigenous deep-water benthic foraminifers only. 4. Watznauria spp. in a matrix of clay and overgrown carbonate particles, $\times 3000.5$. Cretarhabdus spp. in a splintered, porous clay matrix, $\times 3000.6$. Close-up of 5, showing etching and overgrowth of Cretarhabdus spp., whose central area structures are obscured by authigenic fused clay particles, $\times 10,000$. 

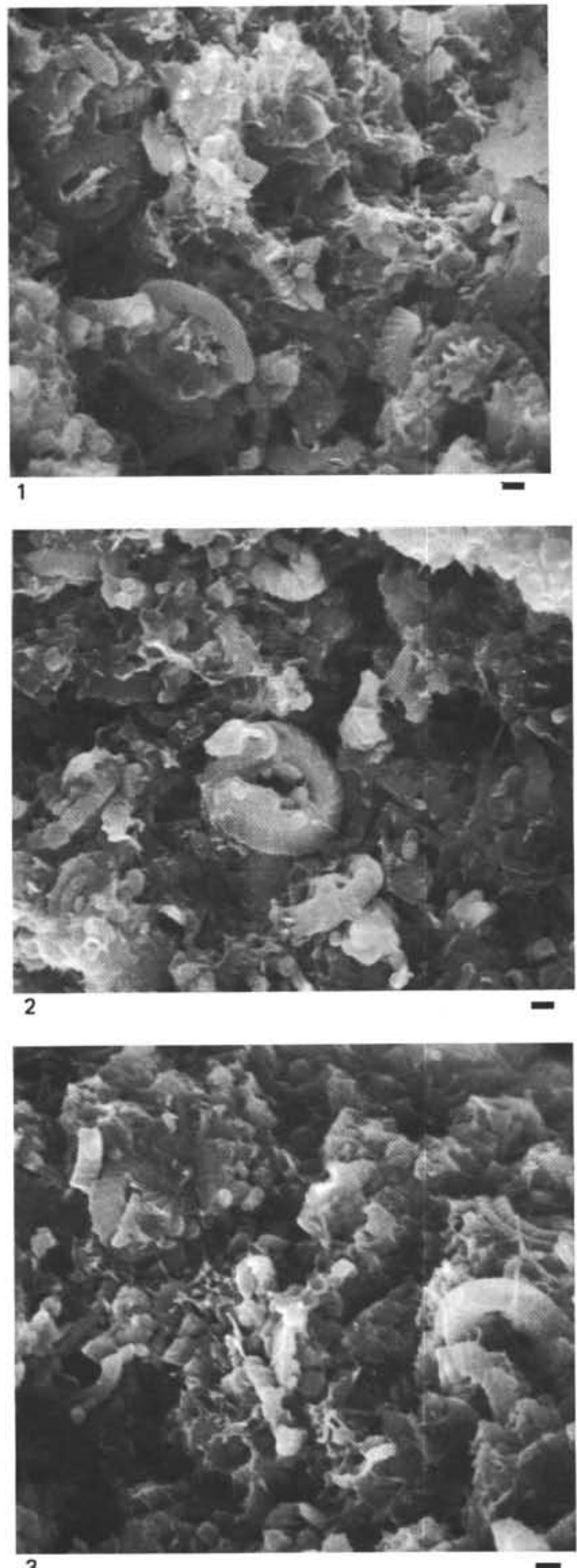
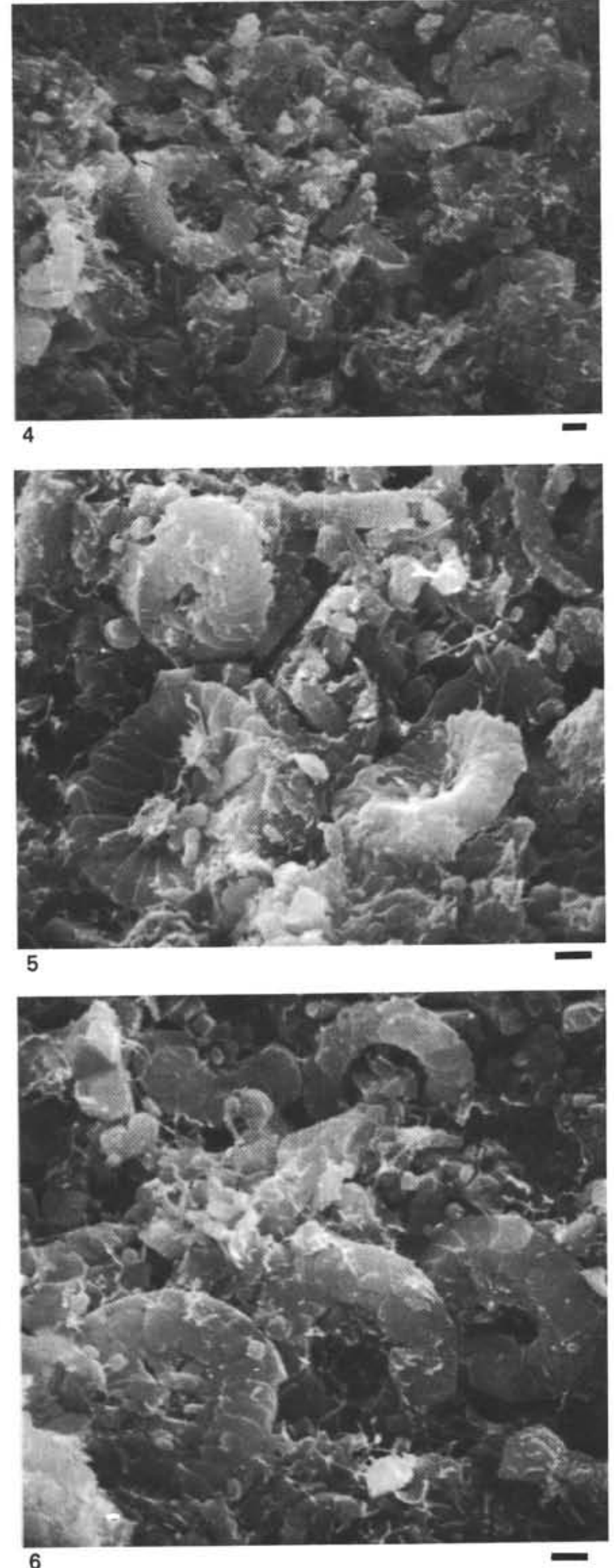

Plate 2. Scanning electron micrographs of lower Campanian nannofacies. Scale bars $=1 \mu \mathrm{m}$.

Figures 1-3. Sample 462-55-2, 71-73 cm. Tan, zeolitic marlstone with indigenous deep-water benthic foraminifers only. 1. Common, strongly etched and broken nannofossils embedded in clay matrix, $\times 3000.2$. Imprint of nannofossil in clay matrix, above strongly dissolved Watznaueria barnesae, (distal view) $\times 3000$. 3. Nannofossil remains dispersed in compact clay matrix with numerous imprints of coccoliths in upper half of photograph, $\times 3000$.
Figures 4-6. Sample 462-55-4, 55-59 cm. Zeolitic marlstone with indigenous deep-water benthic foraminifers only. 4. Moderately well-preserved calcareous nannofossils dominating the fine clay matrix. Fine threads are probably hypha from post-recovery fungus growth, $\times 3000$. 5. Distal and proximal views of Watznaueria barnesae with signs of moderate overgrowth, $\times 5000.6$. Placolith shields with central-area structures partially dissolved, embedded in fine-grained clay and coccolith-debris matrix, $\times 5000$. 

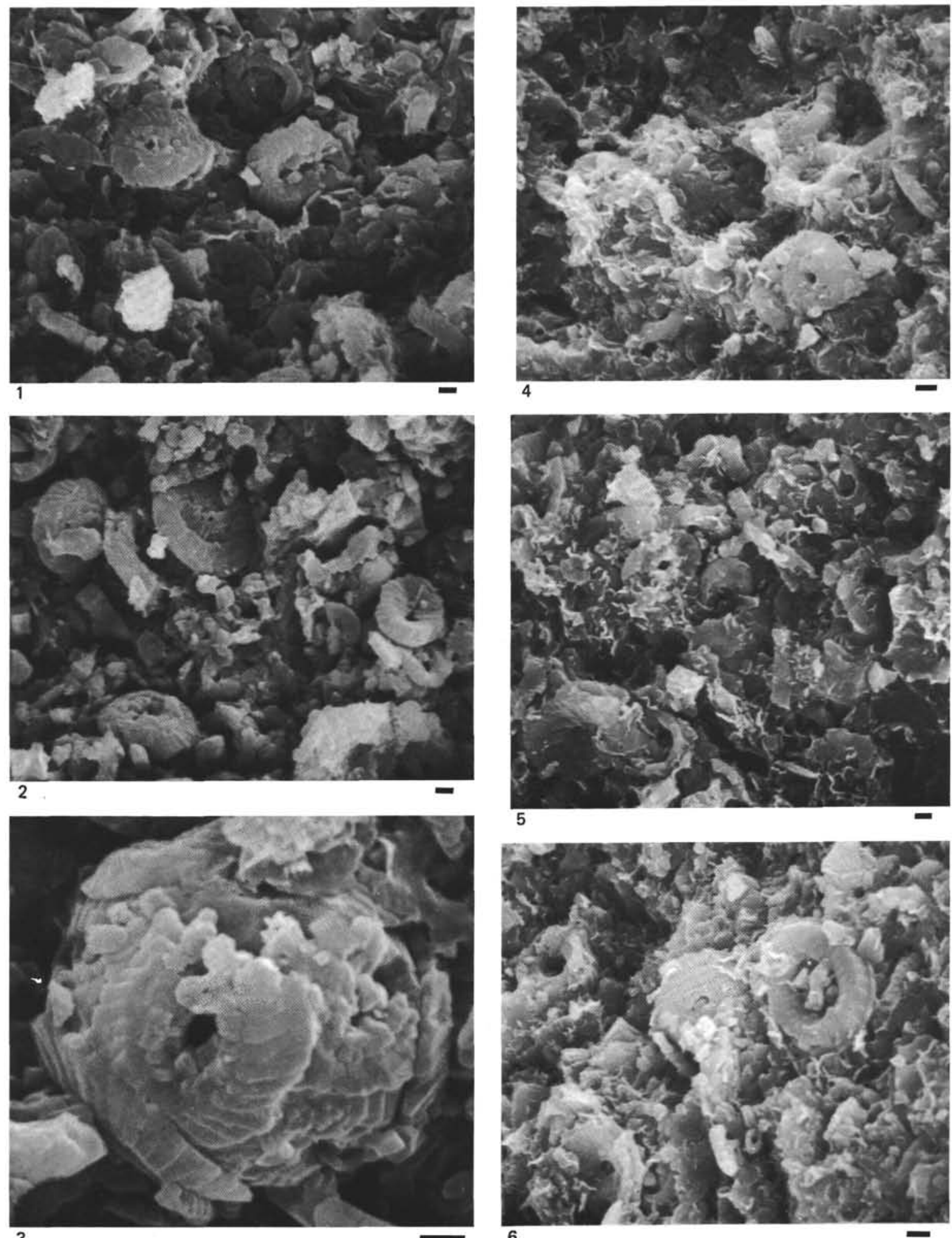

3

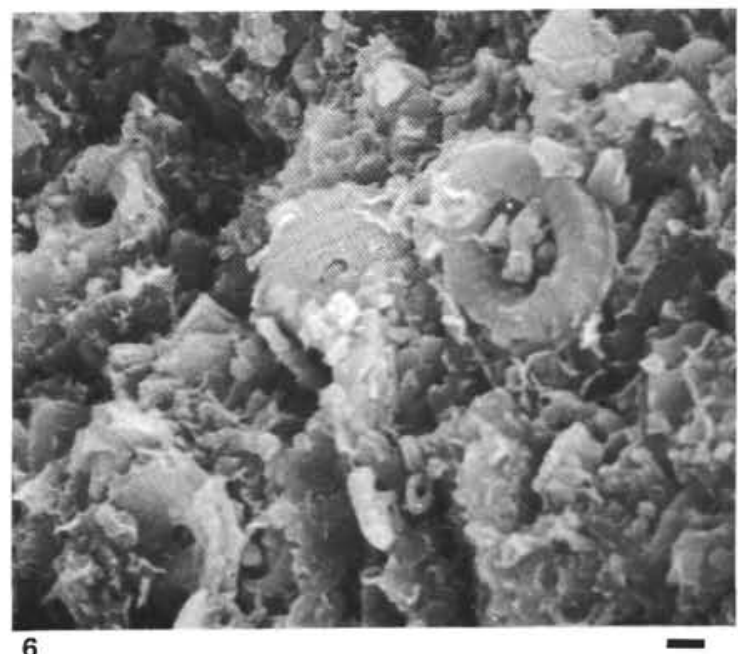

Plate 3. Scanning electron micrographs of lower Campanian nannofacies. Scale bars $=1 \mu \mathrm{m}$.

Figures 1-3. Sample 462-55-2, 61-64 cm. Tan marlstone with transported benthic foraminifers. 1. Common calcareous nannofossils of dominantly solution-resistant taxa, dispersed in matrix of clay and coccolith debris, $\times 3000$. 2. Well-preserved Cretarhabdus crenulatus (distal view, upper center) and moderately well-preserved Watznaueria barnesae (distal views: upper left and lower left; proximal view: right center of micrograph), showing dissolu-

tion in central area and overgrowth of shield elements, $\times 3000.3$. Coccosphere of Watznaueria barnesae with partially dissolved coccoliths, $\times 8000$.

Figures 4-6. Sample 462-55-1, 85-89 $\mathrm{cm}$. Brown marlstone with transported benthic foraminifers. 4 . Moderately well-preserved calcareous nannofossils packed in dense clay matrix, $\times 3000.5,6$. Common, well-preserved, slightly overgrown calcareous nannofossils wrapped in flaky clay matrix, interspersed with coccolith debris, $\times 3000(5), \times 4000(6)$. 


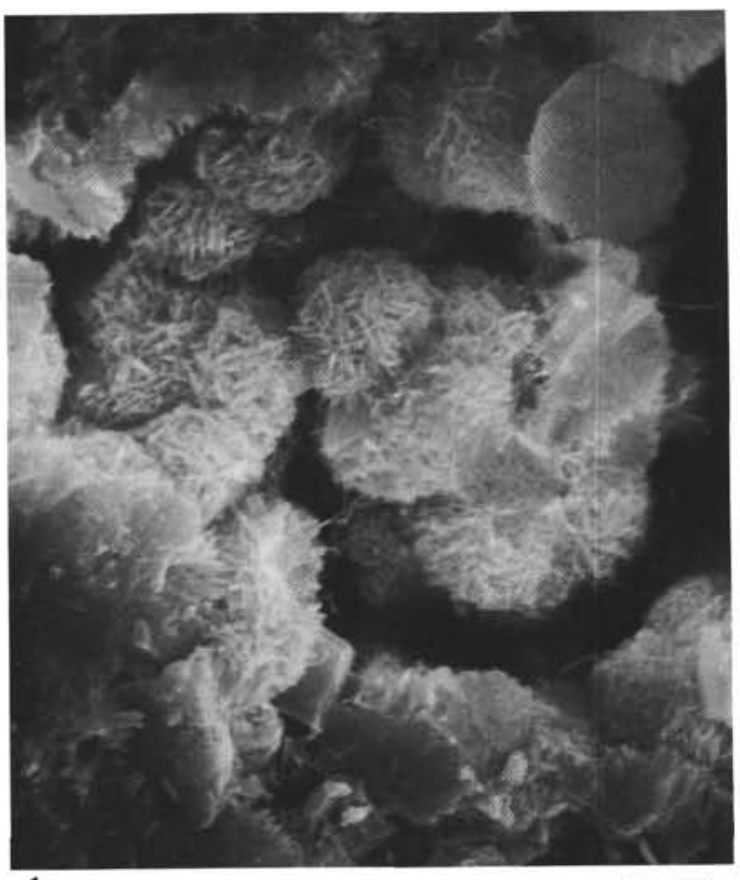

1

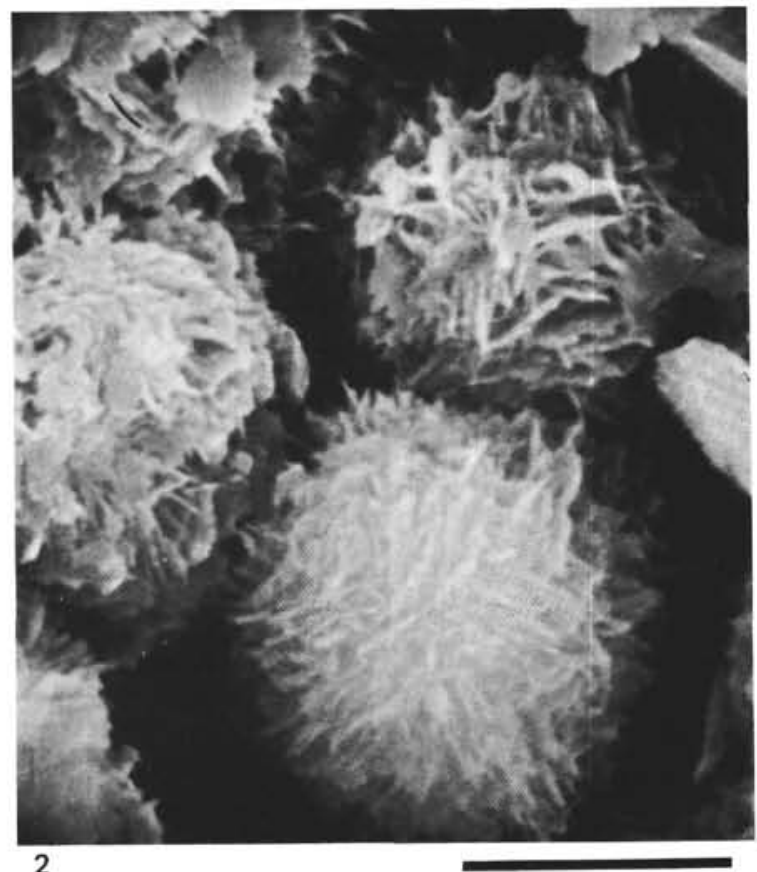

Plate 4. Scanning electron micrographs of lower Campanian nannofacies. Scale bars $=1 \mu \mathrm{m}$.

Figures 1-5. Sample 462-55-2, 64-66 cm. Dark-brown claystone with indigenous benthic foraminifers only. 1, 2, 5. Aggregates of cristo-
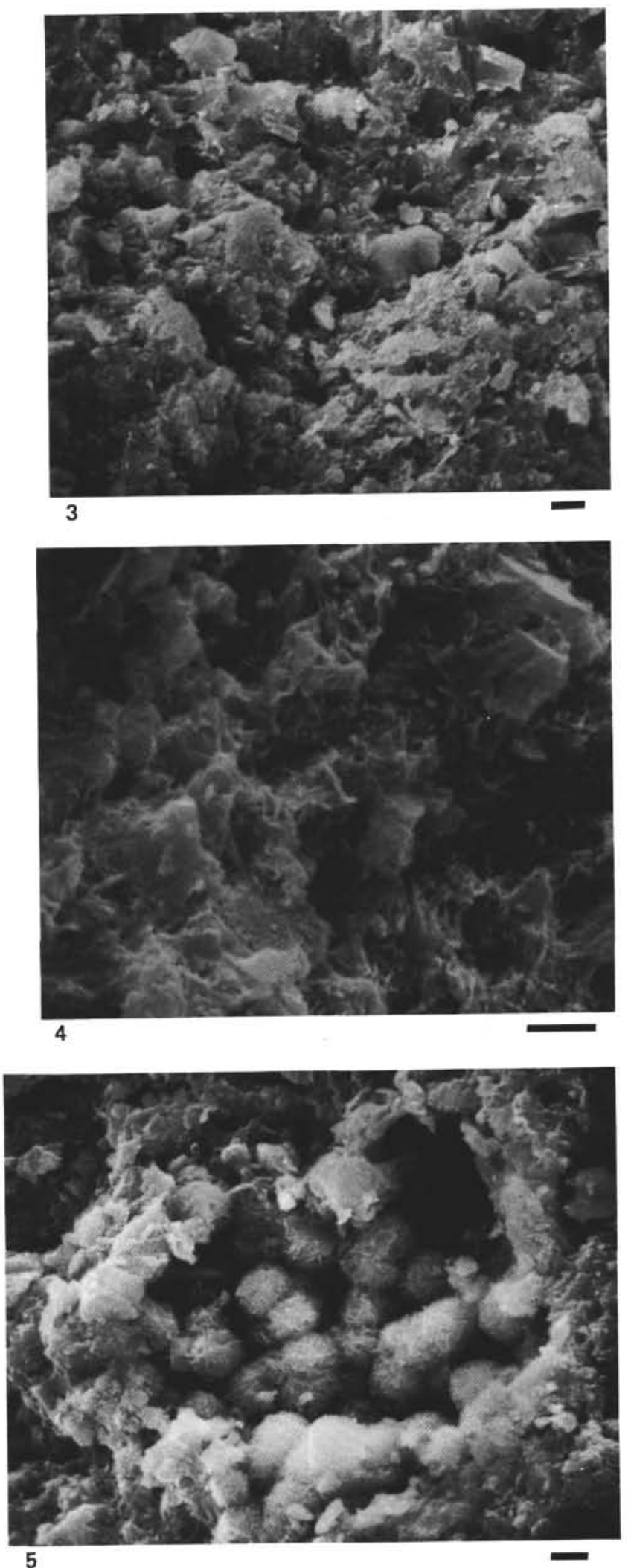

balite spherules developed diagenetically in fine clay matrix, $\times 2000(1), \times 6000(2), \times 1000$ (5) $.3,4$. Poorly structured clay matrix, $\times 1000(3), \times 2000(4)$. 

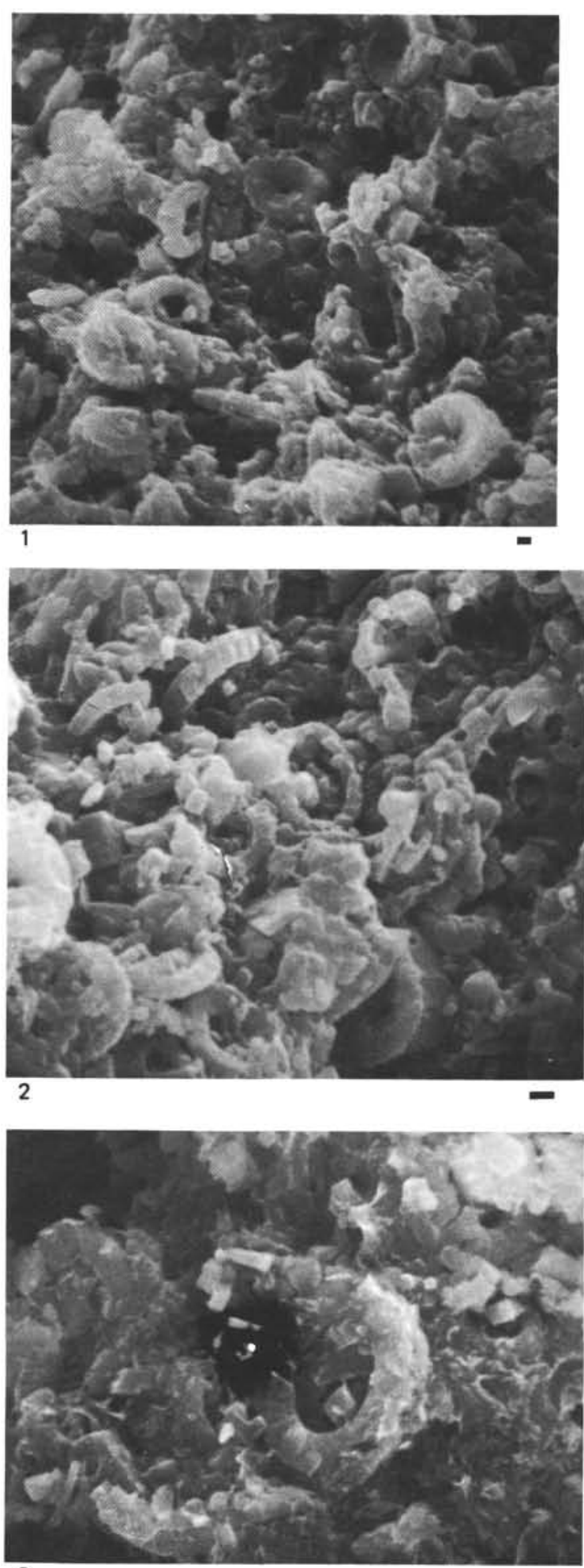

3

Plate 5. Scanning electron micrographs of upper Campanian nannofacies. Scale bars $=1 \mu \mathrm{m}$.

Figures 1, 2, 4. Sample 462-54-3, 3-7 cm. Marly limestone with transported benthic foraminifers. 1 . Common, moderately overgrown calcareous nannofossils (mostly Watznaueria barnesae), embedded in rather porous coccolith debris and clay matrix, $\times 2000.2$. Moderately etched and overgrown nannofossils in porous matrix
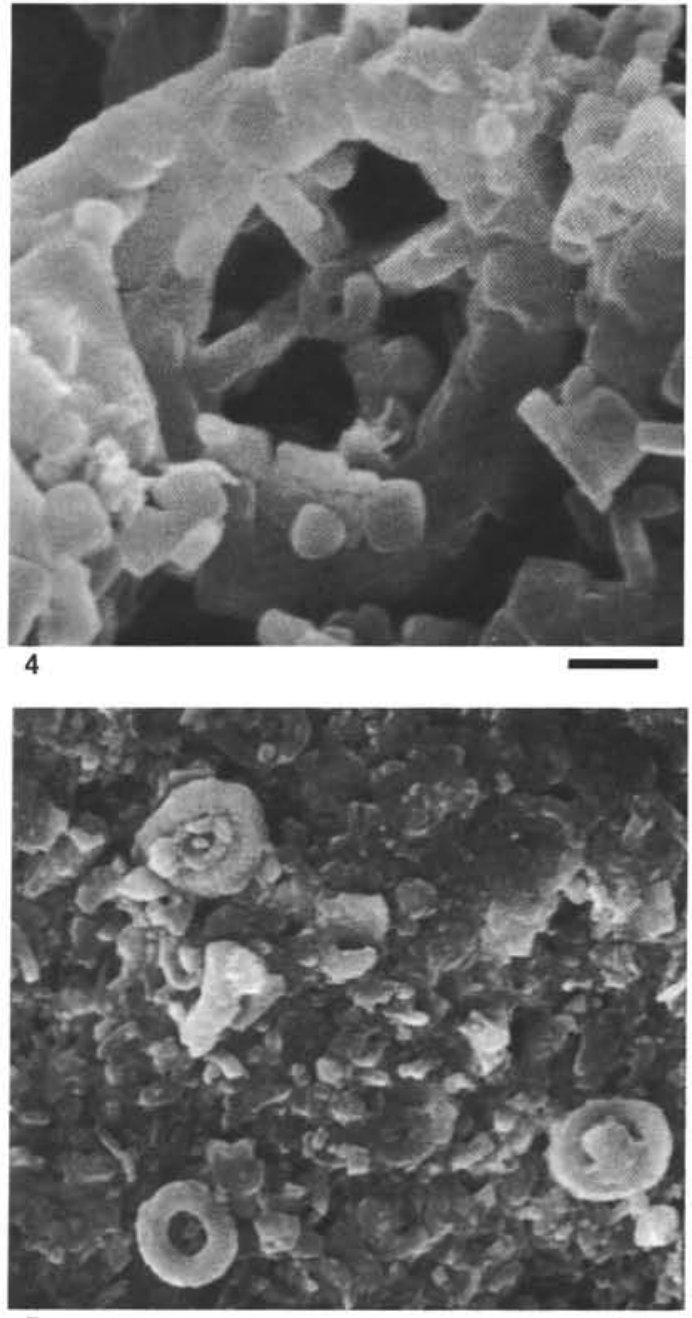

5

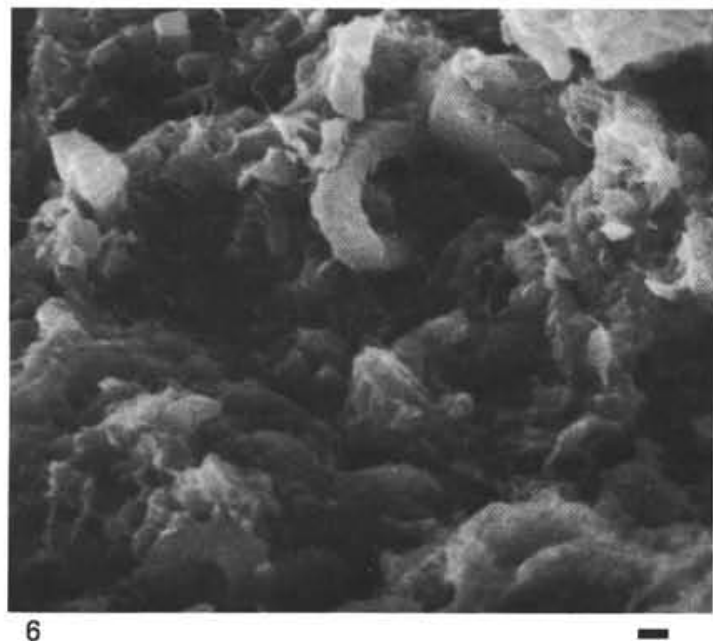

consisting dominantly of relatively coarse carbonate debris, $\times 3000$. 4. Proximal view of Prediscosphaera cretacea, showing fusion of elements with carbonate debris by overgrowth, $\times 10,000$. Figures $3,5,6$. Sample 462-54-2, 67-72 cm. Marly limestone with indigneous benthic foraminifers only. 3, 6. Few, strongly etched nannofossil shields are packed in dense matrix of clay particles and coccolith debris, $\times 3000$. 5 . Coccoliths and clay particles, showing preferred orientation, $\times 2000$. 

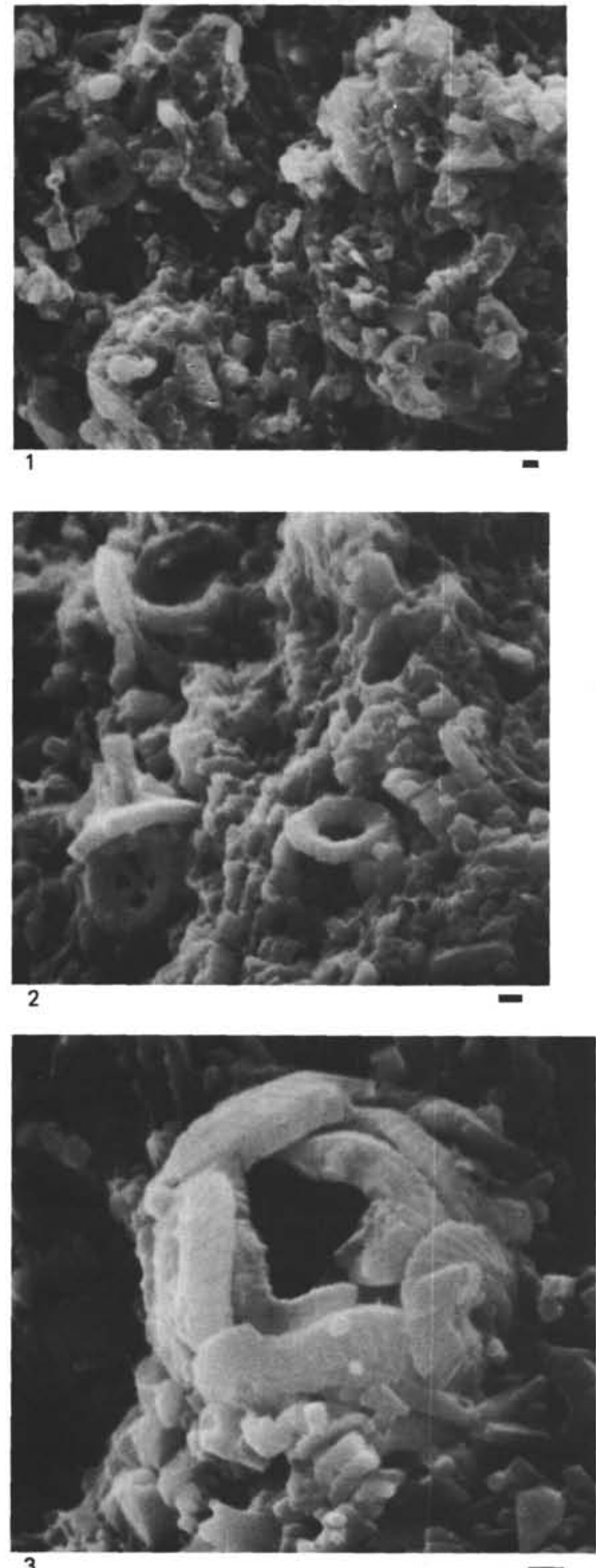

3

Plate 6. Scanning electron micrographs of upper Campanian nannofacies. Scale bars $=1 \mu \mathrm{m}$.

Figures 1-3. Sample 462-54-1, 123-125 cm. Laminated, marly limestone with transported benthic foraminifers. 1, 2. Nannofossils and nannofossil debris, making up the bulk of the sediment, solution-susceptible Prediscosphaera cretacea abundant, $\times 2000$ (1), $\times 3000$ (2). 3. Coccosphere of Watznaueria barnesae, partially dissolved, $\times 5000$.
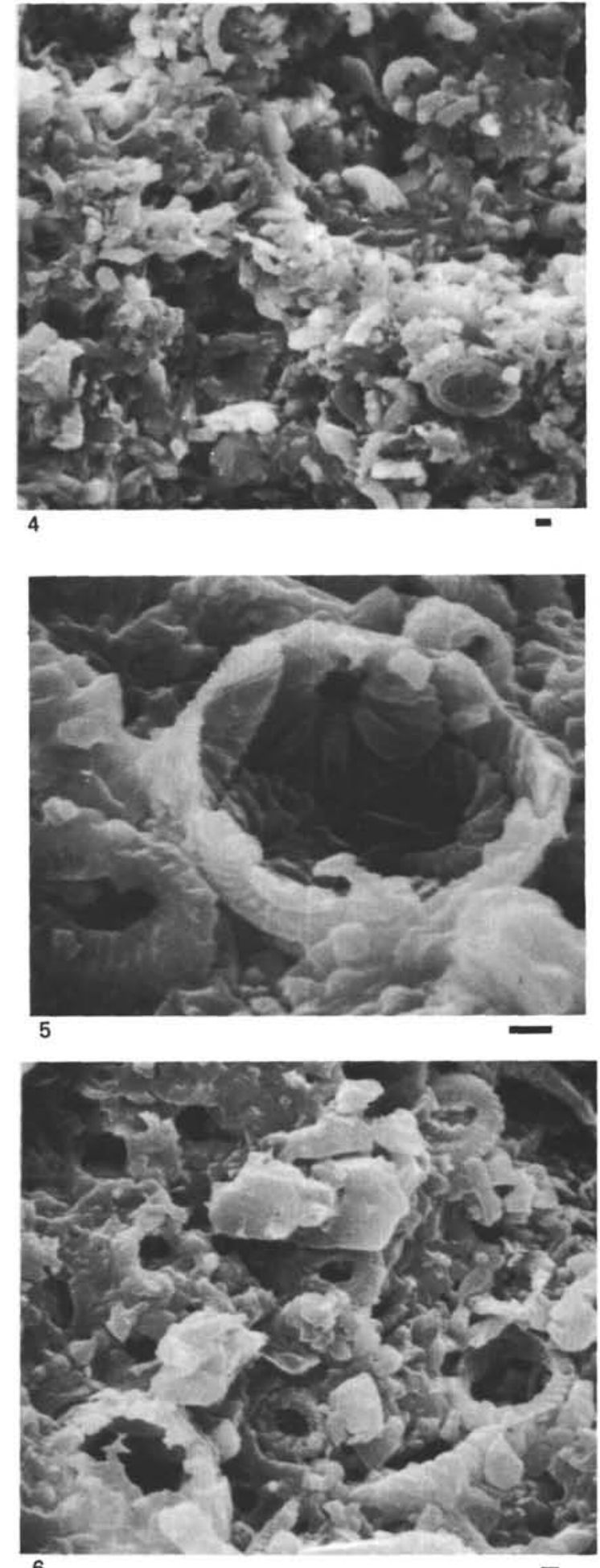

6

Figures 4-6. Sample 462-54-1, 39-45 cm. Burrowed marly limestone with transported benthic foraminifers. 4. Nannofossils and nannofossil debris dispersed in relatively coarse-grained clay matrix, $\times 2000$. 5. Broken coccosphere of Cyclagelosphaera margerelii, showing overgrowth on proximal shields, Watznaueria barnesae in left lower corner strongly dissolved, $\times 6000$. 6 . Moderately wellpreserved nannofossils dispersed in relatively coarse and porous carbonate debris and clay matrix, coccosphere of Watznaueria barnesae in lower left corner, $\times 2000$. 

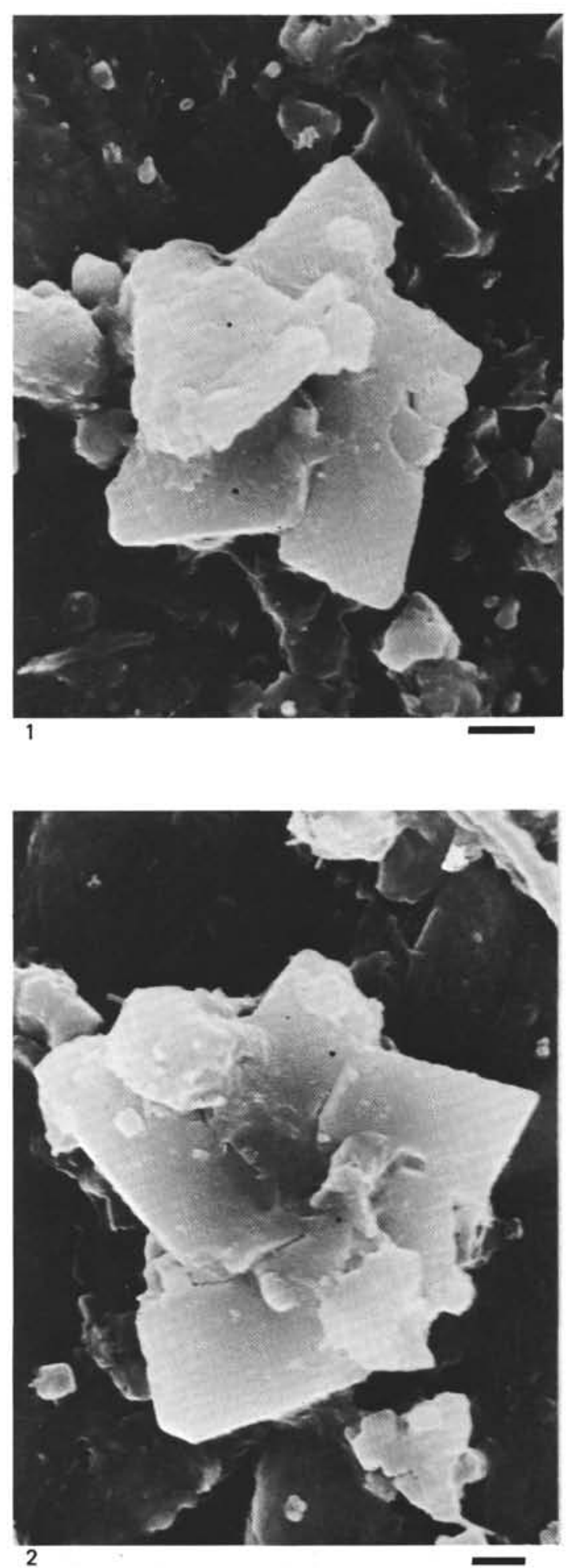

Plate 7. Scanning electron micrographs of early Campanian Braarudosphaera (sp. indet.) in disaggregated Sample 462-55-4, 37-40 $\mathrm{cm}$. Scale bars $=1 \mu \mathrm{m}$.

Figure 1. Proximal view of pentalith, showing overgrowth of calcite crystals, incorporating carbonate debris and leading to radial asymmetry of pentalith, $\times 9800$.

Figure 2. Proximal view of asymmetric pentalith showing central pit, $\times 7400$.
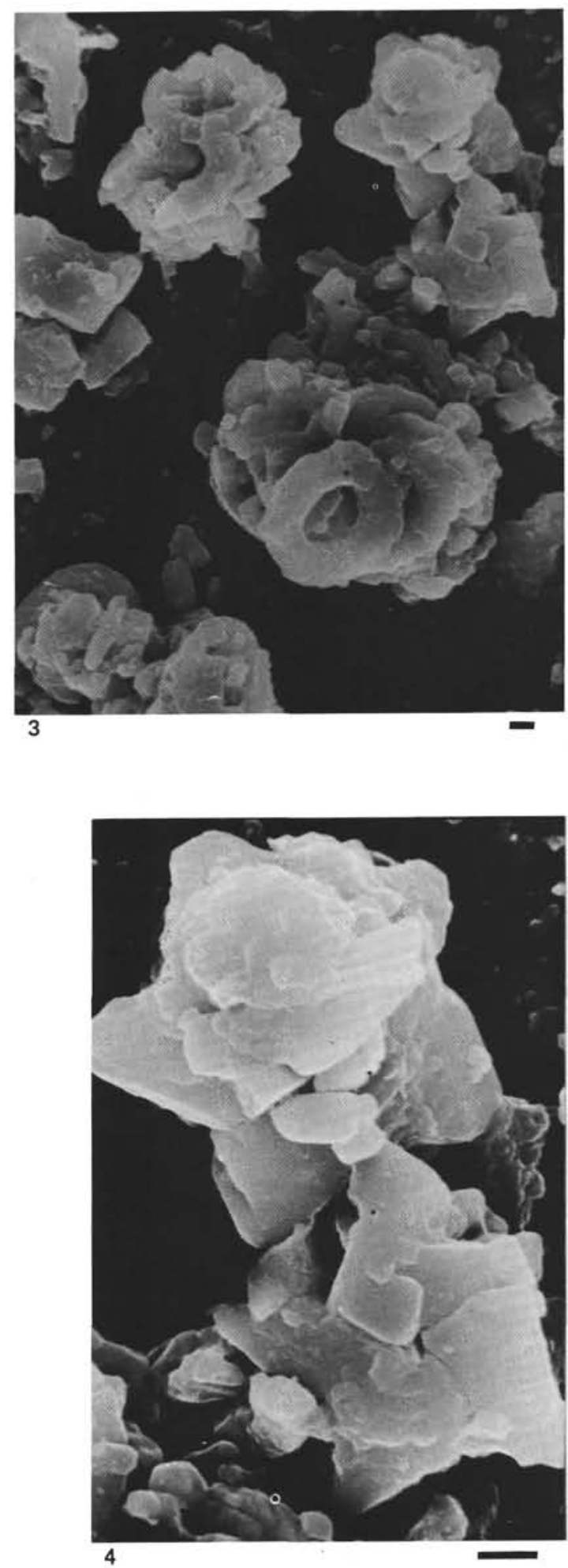

Figure 3. Moderately well-preserved nannofossils with two specimens of Braarudosphaera (sp. indet.), $\times 3200$.

Figure 4. Distal view of Braarudosphaera (sp. indet.) in upper part of of micrograph, showing sloping, re-calcified crystal surfaces; central part obscured by debris; proximal view of Braarudosphaera sp. indet.) in lower part of micrograph, with interlocking overgrowth features on some elements, $\times 8600$. 